\title{
Material positioning influence towards fatigue strength of the friction stir processed AA8011/AA6082 joints
}

\author{
Velaphi Msomi ${ }^{1}$ and Sipokazi Mabuwa ${ }^{1}$ \\ ${ }^{1}$ Cape Peninsula University of Technology - Bellville Campus
}

May 20, 2020

\begin{abstract}
The investigation on the fatigue behaviour of the processed friction stir welded AA8011/AA6082 dissimilar joint is reported in this work. The single-pass friction stir processing technique was applied on the friction stir welded AA8011/AA6082 and AA6082/AA8011 dissimilar joints. The friction stir processing was conducted under normal conditions (room temperature). The samples were prepared for different analysis using the waterjet cutter technology. The tests conducted include tensile, microstructural analysis, microhardness, fatigue and fracture surface morphology. The microstructural analysis revealed a correlation between material positioning and grain sizes. There was a notable decrease in grain size when AA6082 was positioned on the advancing side during processing. The tensile properties of the joint processed with AA6082/AA8011 were found to be higher compared to the joint produced with AA8011/AA6082. The AA6082/AA8011 joint was found to be more ductile compared to AA8011/AA6082 joint. The stir zone microhardness for the AA8011/AA6082 and AA6082/AA8011 joints was measured to be approximately $60 \mathrm{HV}$ and $80 \mathrm{HV}$, respectively. The fatigue strength of AA6082/AA8011 was found to be higher compared to AA8011/AA6082 fatigue strength.
\end{abstract}

Material positioning influence towards fatigue strength of the friction stir processed AA8011/AA6082 joints

Mabuwa $\mathrm{S}^{1}$, Msomi $\mathrm{V}^{1 *}$

${ }^{1}$ Cape Peninsula University of Technology, Mechanical Engineering Department, Faculty of Engineering and the Built Environment, P.O.Box 1906, Bellville, 7535, South Africa.

*Corresponding author: msomiv@gmail.com

Abstract: The investigation on the fatigue behaviour of the processed friction stir welded AA8011/AA6082 dissimilar joint is reported in this work. The single-pass friction stir processing technique was applied on the friction stir welded AA8011/AA6082 and AA6082/AA8011 dissimilar joints. The friction stir processing was conducted under normal conditions (room temperature). The samples were prepared for different analysis using the waterjet cutter technology. The tests conducted include tensile, microstructural analysis, microhardness, fatigue and fracture surface morphology. The microstructural analysis revealed a correlation between material positioning and grain sizes. There was a notable decrease in grain size when AA6082 was positioned on the advancing side during processing. The tensile properties of the joint processed with AA6082/AA8011 were found to be higher compared to the joint produced with AA8011/AA6082. The AA6082/AA8011 joint was found to be more ductile compared to AA8011/AA6082 joint. The stir zone microhardness for the AA8011/AA6082 and AA6082/AA8011 joints was measured to be approximately 60HV and $80 \mathrm{HV}$, respectively. The fatigue strength of AA6082/AA8011 was found to be higher compared to AA8011/AA6082 fatigue strength.

Keywords : Microstructural analysis, tensile properties, microhardness, Fatigue, fracture surface morphology. 


\section{Introduction}

The friction stir welding technique is regarded as the most suitable method of joining aluminium alloys and other soft metals [1]. This includes for both similar and dissimilar metals and alloys. There are numerous investigations that are being in progress which are looking into the compatibility of FSW on the dissimilar aluminium alloys [1-4]. However, it has been noted that there are many factors which compromise the quality and strength of the dissimilar joint. Some of the factors include welding parameters, material positioning and welding surrounding conditions [5-6]. Additionally, the joining of dissimilar materials was found to result in the formation of intermetallic compounds, which is also a major contributing factor towards the weakening of the joint strength [6-7]. This, therefore, opened a gap for a post welding technique to strengthen the joint strength. The friction stir processing technique was found to be a suitable method in modifying the joint/surface properties. The friction stir processing (FSP) works the same way as the from friction stir welding, but it does not join material together but modifies the microstructure of the material [8-9]. FSP has been used successfully to modify both single surfaces and welded joints [10-13].

The FSP technique still has many areas that still need to be investigated. Some of those areas include the impact of FSP on the fatigue life of the processed joint. There is very limited literature available in this area. However, it has been shown by various authors that the occurrence of most structural failures originates from fatigue [14-15]. This then makes it a need that special attention be given to this area as there are high possibility of utilizing dissimilar aluminium alloys in the aerospace and automotive industries. These industries require very high safety, which makes fatigue resistance of joints very pivotal for ensuring the integrity of such structures [16-17].

Hussein and Shammari [18] comparatively studied the FSWed and FSPed AA5083-H111 joint to determine the respective fatigue and fracture behaviour of the joints. The fatigue test were performed under constant stress amplitude cantilever. The analysis of the fatigue properties revealed that the FSPed samples yielded better fatigue limits compared to the FSWed samples. Uematsu and Tokaji [19] employed FSP on the cast aluminium alloy A356-T6 with the purpose of studying its fatigue strength. The fatigue strength of the FSPed A356-T6 was found to be lower than that of the base material, nonetheless, the fatigue limit was significantly improved by FSP. The increase in fatigue limit was said to be due to the elimination of the casting defects during FSP, while the decrease in fatigue strength was due to matrix softening by the dissolution of precipitates caused by heat input during FSP leading to a faster crack growth rate in the FSPed region.

Park et al. [20] discovered that the application of FSP increased the fatigue life of the processed joint by $42 \%$ compared to that of the welded one. Additionally, the fatigue strength was found to increase with a decrease in the microstructural grain size. Similar results were in consistent with those reported in the literature [21]. FSP was employed on the TIG welded AA6061 joint with the aim of increasing the fatigue life of the joint [22]. The constant amplitude loading and a stress ratio of zero were used. The application of FSP resulted in the tensile strength being improved by $5-13 \%$ while the hardness was increased by $5-10 \%$. Subsequently the fatigue strength improvement of about $30-60 \%$ was observed and these improvements were due to the microstructural grain refinement in the stir zone as well as the modification in the geometry occurred at the weld toe.

There is a very limited to no work available that involves the processing of the friction stir welded dissimilar joint. This work is focussing on analysing the impact of the FSP on the friction stir welded AA8011/AA6082 dissimilar joint. The analysis was being performed in relation to the material positioning during FSP.

\section{Materials and Methods}

The $6 \mathrm{~mm}$ thick AA8011 and AA6082-T6 were in the formation of the joint through FSW technique. Table 1 present the chemical compositions and Table 2 present the mechanical properties of the materials. The plates were cut into rectangles of $260 \mathrm{~mm} \times 52 \mathrm{~mm}$. Different material positioning were taken into consideration during welding and processing (see Figure 1). Table 3 shows the parameters used for FSW and FSP. The FSW tool used was made of high-speed steel (HSS) AISI 4140 [25]. The same tool used for FSW was used 
for FSP.

Table 1. Chemical compositions [23-24].

\begin{tabular}{|c|c|c|c|c|c|c|c|}
\hline & $\mathrm{Mg}$ & Zn & $\mathbf{T i}$ & & $\mathrm{Cr}$ & $\mathrm{Si}$ & Mn \\
\hline AA8011 AA6082-T6 & $0.280 .6-1.2$ & $0.0840 .0-0.2$ & \multicolumn{2}{|c|}{$0.0160 .0-0.10$} & $0.0280 .0-0.20$ & $0.520 .7-1.3$ & 0.460 .0 \\
\hline & \multicolumn{3}{|c|}{ Ultimate tensile strength (MPa) } & \multicolumn{2}{|c|}{ Elongation (\%) } & \multicolumn{2}{|c|}{ Microhardness (HV) } \\
\hline AA8011 AA6082-T6 & \multicolumn{3}{|l|}{94.1308} & \multicolumn{2}{|c|}{40.1725 .42} & 33.589 .6 & \\
\hline
\end{tabular}

Table 3. FSW/P conditions.

\begin{tabular}{lllll}
\hline Tool shoulder diameter $(\mathrm{mm})$ & Tool probe diameter $(\mathrm{mm})$ & Tool tilt $\left(^{\circ}\right)$ & Pin length $(\mathrm{mm})$ & Dwell time $(\mathrm{s}$ \\
\hline 20 & 7 & 2 & 5.6 & 10 \\
\hline
\end{tabular}

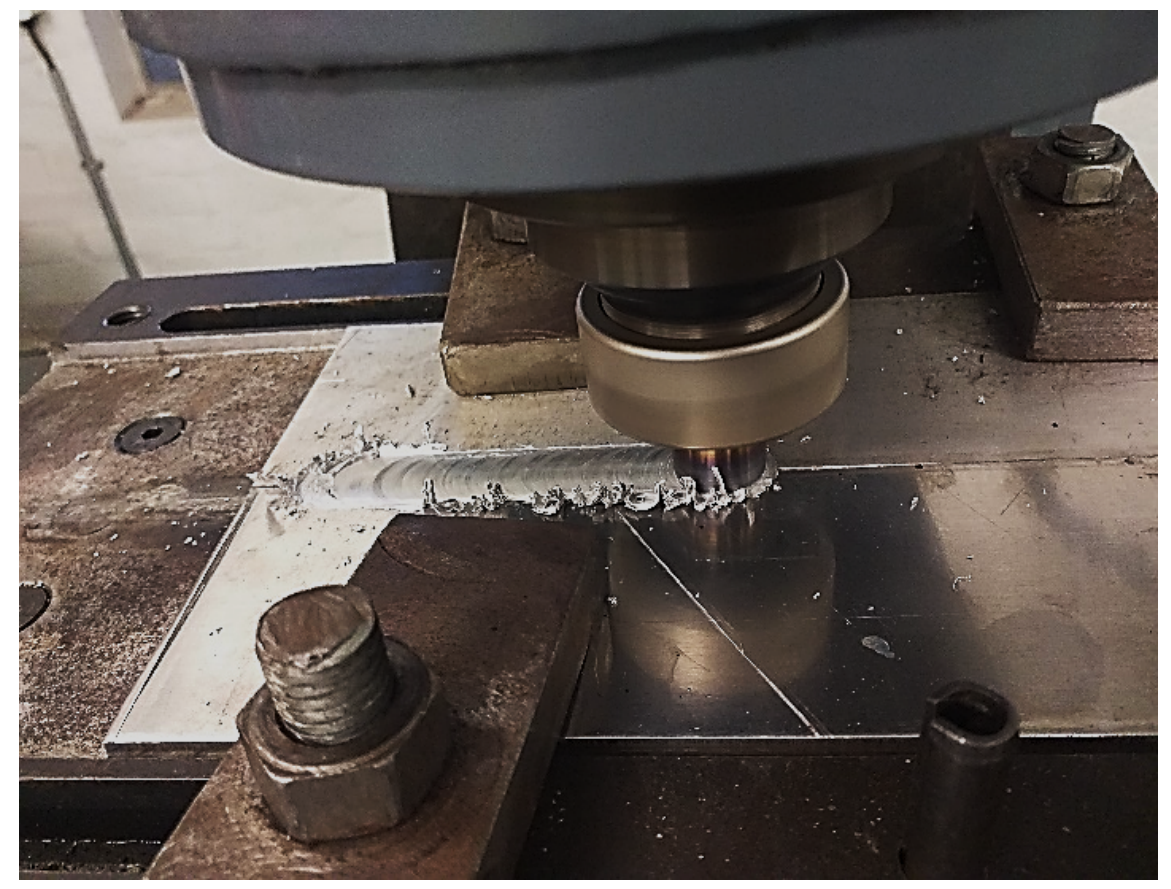




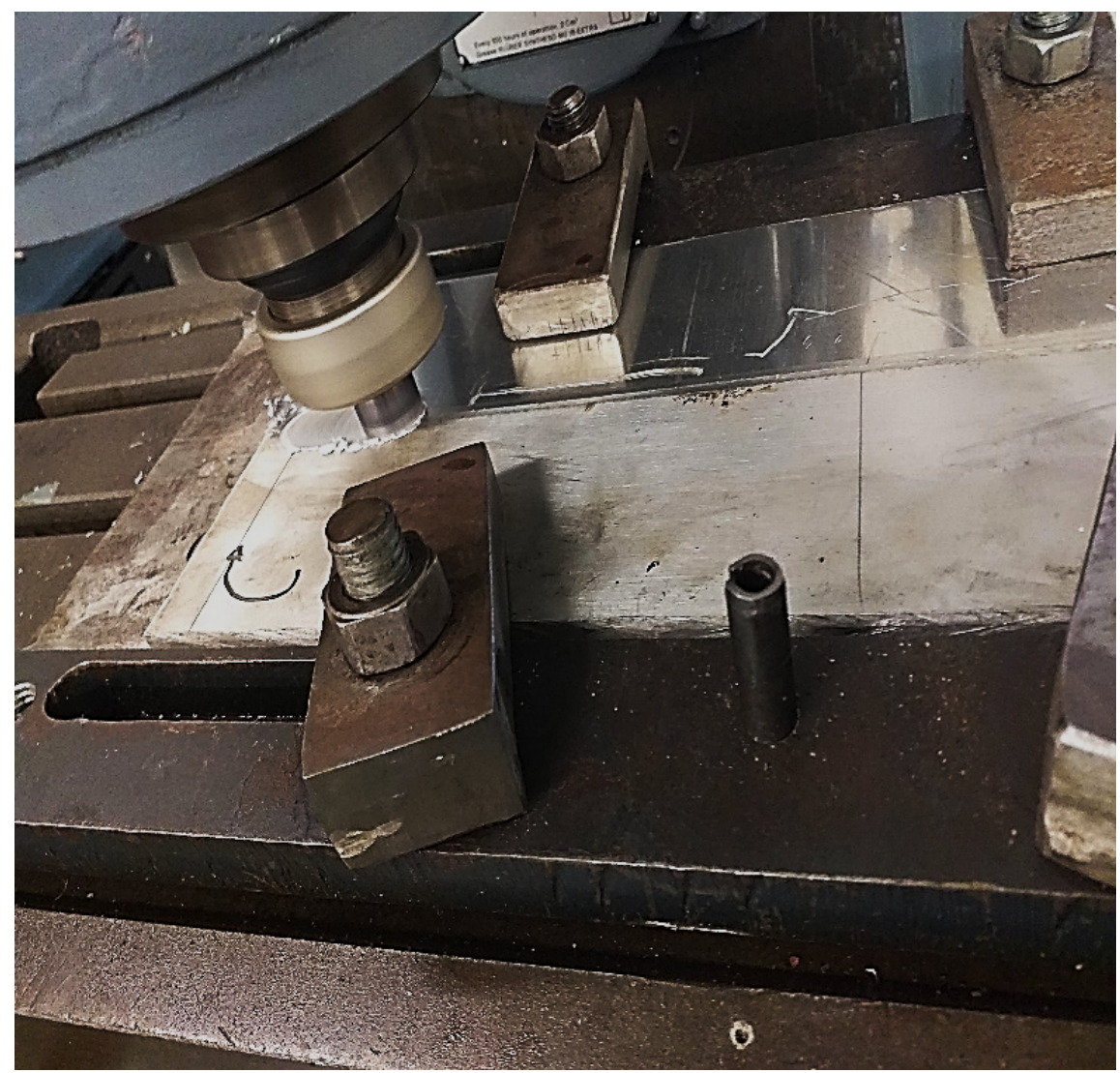

Figure 1. FSW setup, AS-advancing side, RS-retreating side, (a) AA8011-AS and (b) AA6082-AS.

The friction stir processed (FSPed) plates were cut with respect to the tests to be done using water-jet technology. The tests conducted were the microstructural analysis, tensile tests, hardness and fatigue tests. The microstructural analysis was performed using the metallurgical microscope. The specimens were grinded, polished and chemically etched prior the analysis. The chemical etchants used were the modified Keller's reagent $\left(10 \mathrm{ml} \mathrm{HNO}_{3}, 1.5 \mathrm{ml} \mathrm{HCL}, 1.0 \mathrm{ml} \mathrm{HF}\right.$ and $87.5 \mathrm{ml}$ distilled $\left.\mathrm{H}_{2} \mathrm{O}\right)$ and Weck's reagents $(1 \mathrm{~g} \mathrm{NaOH}$, $4 \mathrm{~g} \mathrm{KMnO}_{4}$ and $100 \mathrm{ml}$ distilled $\mathrm{H}_{2} \mathrm{O}$ ). The Vickers hardness test was performed using the Falcon 5000 hardness testing machine through the guidance of ASTM E384-11 standard. The Hounsfield H25K tensile testing machine with Horizon operating software was used to perform the tensile tests. The ASTM-E8M-04 standard was used in designing tensile specimen and also the performance of the tests. The fatigue tests were conducted using the Instron $8801(100 \mathrm{kN})$ with Bluehill-3 operating software. The fatigue was performed based on the ASTM: E466-07 standard. The fatigue tests were conducted at a frequency of $20 \mathrm{~Hz}$ with the minimum and the maximum amplitudes of $30 \%$ and $80 \%$ of the ultimate tensile strength (UTS).

\section{Results and discussion.}

\section{Tensile Strength}

Figure 2 shows the tensile stress and strain curves of the friction stir processed FSWed joints. The AA6082/AA8011 joint recorded the maximum UTS of $91.45 \mathrm{MPa}$ with $22.28 \%$ of percentage elongation whereas AA8011/AA6082 joint recorded a maximum UTS of $85.1 \mathrm{MPa}$ with a percentage elongation of $20.22 \%$. This therefore means that positioning of AA6082 on the advancing side resulted in better tensile properties in comparison to AA8011 on the advancing side. However, the tensile strength of the joints was found to be lower than the parent materials (see Figure 2(b)). This is due to the tensile specimens failing on the position of softer regions in which is mostly referred to as the weakest point [26-29]. In the present 
case both specimens failed at the heat affected zone (HAZ) on the side of AA8011 material. The positions of fracture suggest that the FSPed joints were stronger compared to the base material AA8011 and similar trend has been reported in the literature [30-32].

\section{Hosted file}

image3.emf available at https://authorea.com/users/324395/articles/452595-materialpositioning-influence-towards-fatigue-strength-of-the-friction-stir-processed-aa8011aa6082-joints

\section{Hosted file}

image4.emf available at https://authorea.com/users/324395/articles/452595-materialpositioning-influence-towards-fatigue-strength-of-the-friction-stir-processed-aa8011aa6082-joints

Figure 2. Friction stir processed FSWed, (a) Tensile stress-strain curves and (b) Tensile strengths bar charts.

Figure 3 presents the fracture surface morphology of the tensile specimens. The tensile specimens failed at the HAZ of the AA8011 which is the alloy with low strength hence both joints showed a similar fractographs. The ductile failure mode characterize by quasi state cleavage, dimples, matrix cracks, microvoids and tear ridges were observed $[29,33]$.

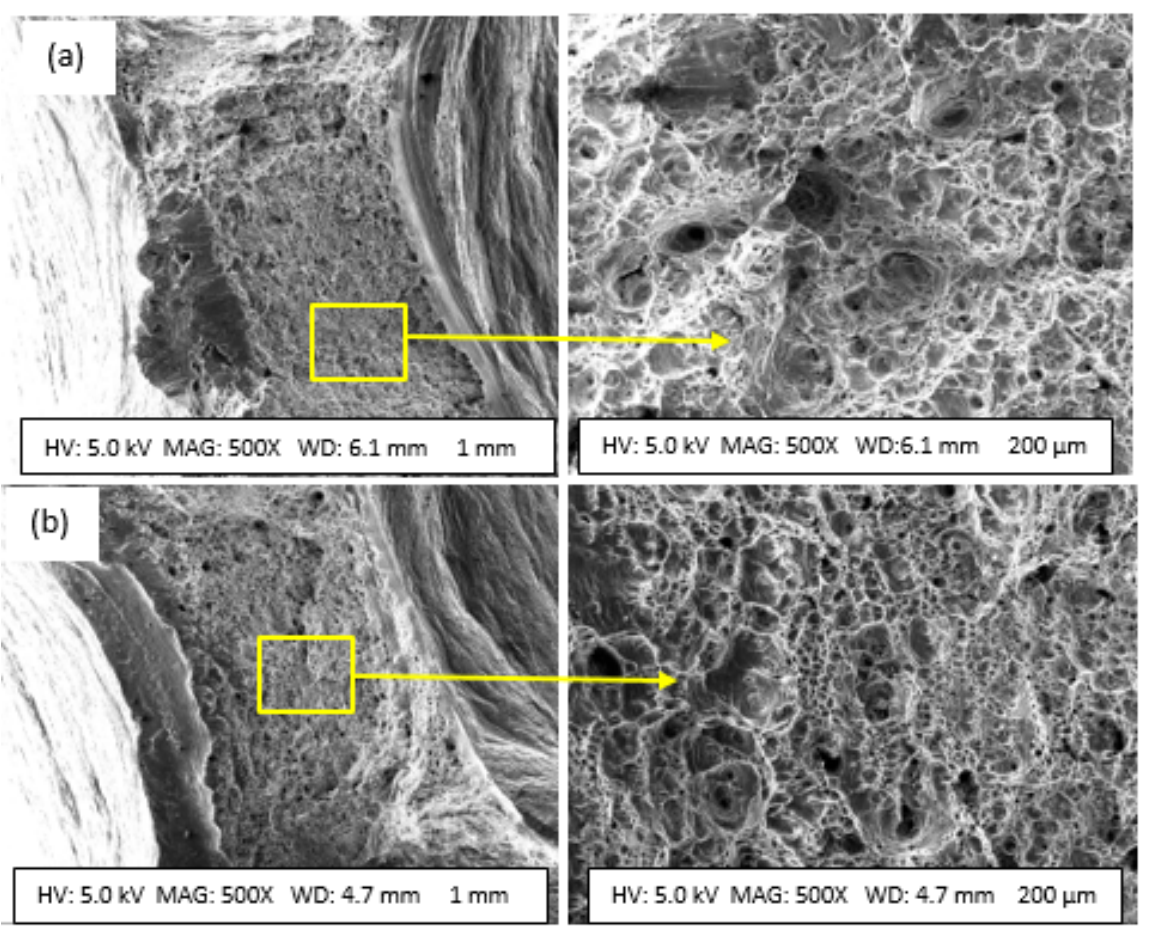

Figure 3. Fractographs for the friction stir processed FSWed joints, (a) AA6082/AA8011, (b) AA8011/AA6082.

\section{Microhardness}

The Vickers microharness profiles of the friction stir processed FSWed joints are presented in Figure 4. The microhardness profile of the AA6082/AA8011 joint showed a decreasing path from the advancing side across the nugget zone (NZ) towards the reatreating side. The microhardness profile of AA8011/AA6082 joint showed a gradual increase from the advancing side towards the retreating side. The maximamum 
microhardness value of about $72 \mathrm{HV}$ for AA6082/AA8011 joint was recorded next to thermos-mechanically affected zone (TMAZ) of AA6082. The maximum microhardness value of about $56 \mathrm{HV}$ for AA8011/AA6082 joint was also recorded on the TMAZ region of AA6082. Both microhardness values of the friction stir processed joints were both lower compared to the base metals and this behaviour is normally associated with dissimilar aluminium alloyjoints [33-35].

\section{Hosted file}

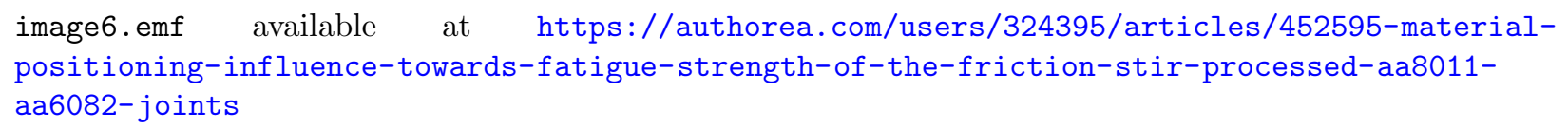

Figure 4. Friction stir processed FSWed microhardness profiles.

\section{Microstructural analysis}

Figure 4 shows the optical micrographs of the base materials and friction stir processed FSWed joints. The AA6082 base material showed an elongated coarse grain structure with mean grain diameters of 36.08 $\mu \mathrm{m}$ leaning towards the rolling direction (Figure 4(a)). The AA8011 base material microstructure also showed coarse elongated grains with a mean grain size of $29.36 \mu \mathrm{m}$. The microstructure of the FSPed AA6082/AA8011 and AA8011/AA6082 joints consisted of three zones namely TMAZ, the heat affected zone (HAZ) and NZ. It was observed that thegrain size was not affected at the HAZ region post FSP. The TMAZ grain structure consisted of deformed and elongated grains which are as result of the processing tool mechanical action [29]. The TMAZ is generally wearker than the nugget zone but stronger than the HAZ region due to grain size variations [11]. The nugget zones of both joints consisted of fine and equiaxed grain structure. This was due to the high temperature experienced by the NZ and the dynamic re-recrystallization which occurred during the processing $[11,25,36]$. The AA6082/AA8011 friction stir processed FSWed joint had a mean grain diameter of $3.98 \mu \mathrm{m}$ while the AA8011/AA6082 was $5.87 \mu \mathrm{m}$.

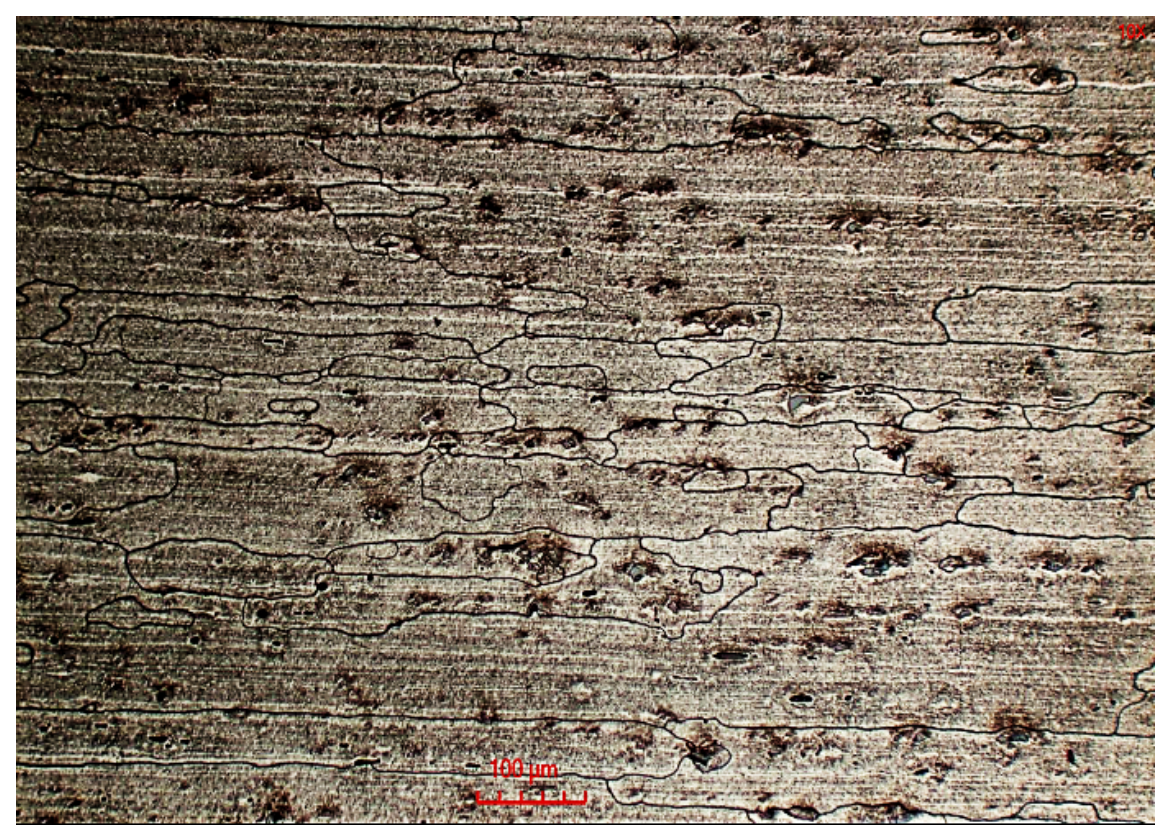



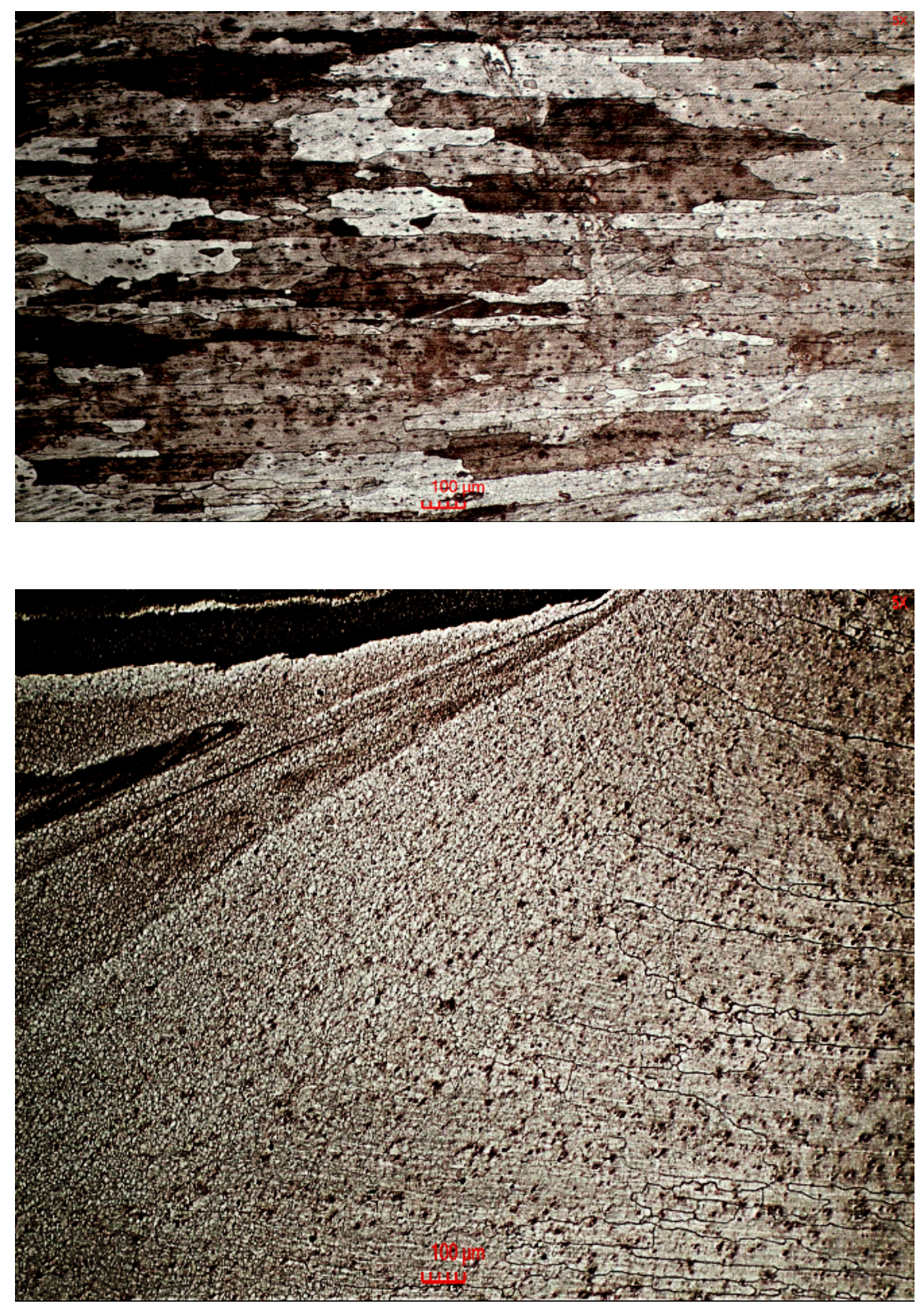

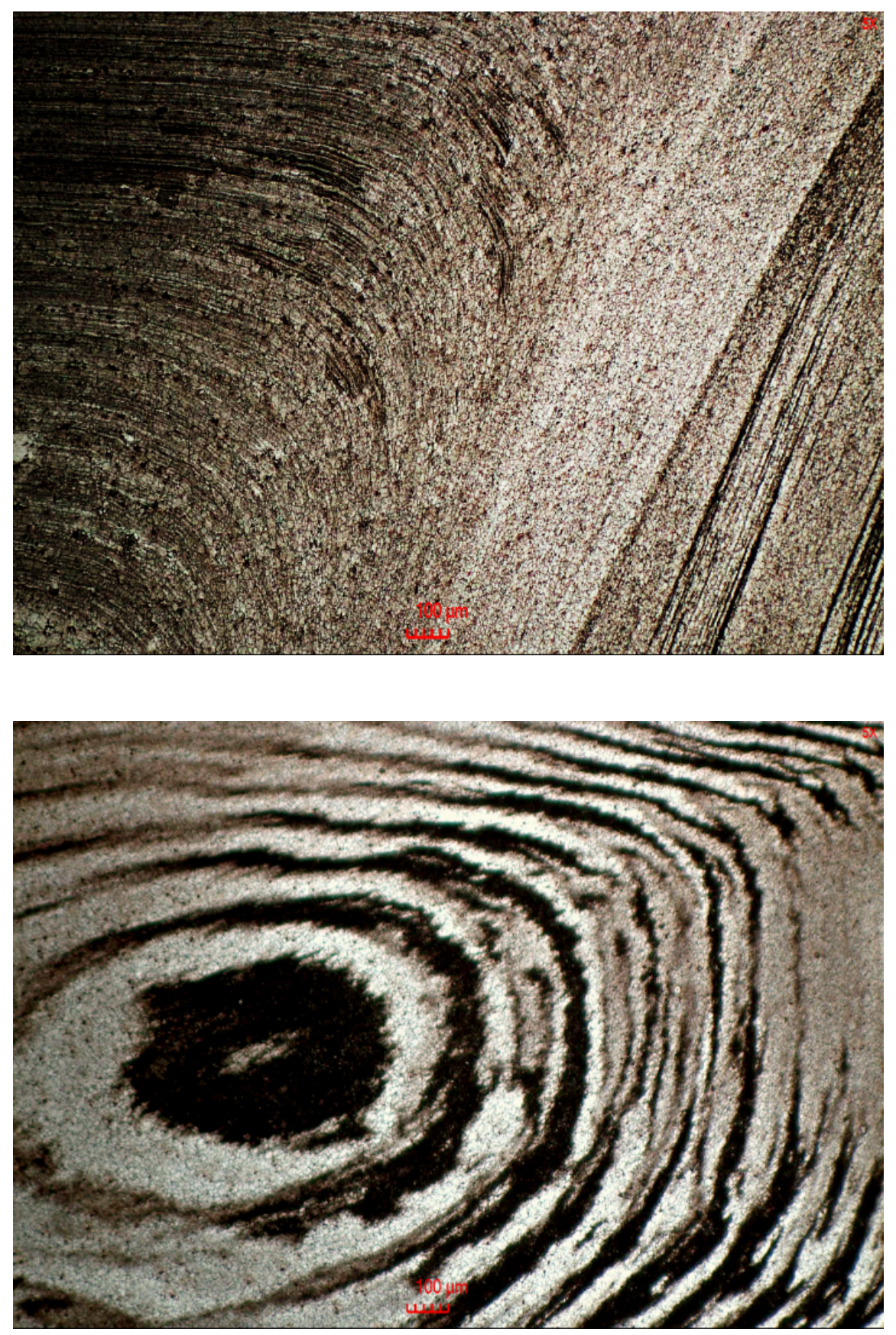

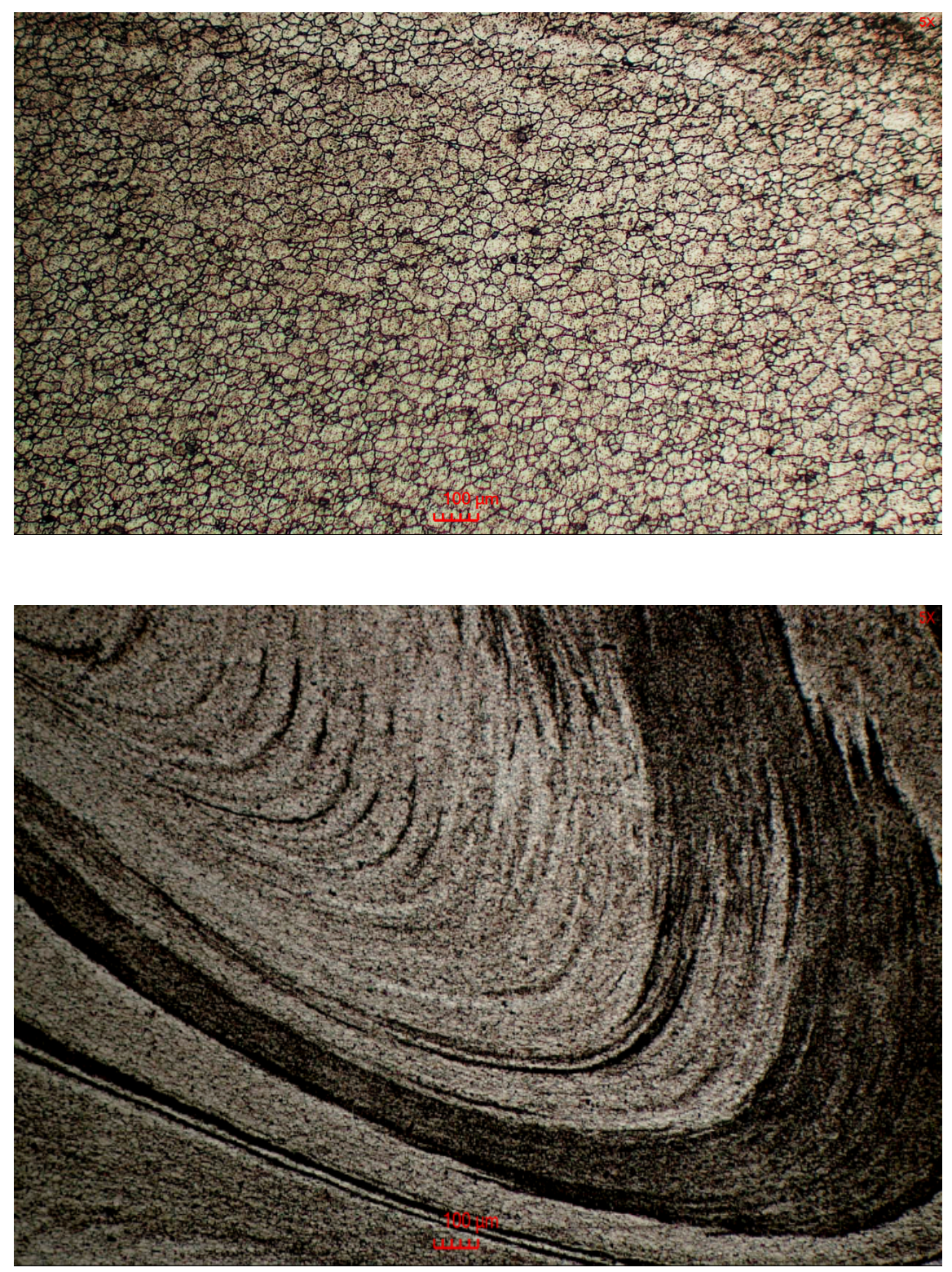


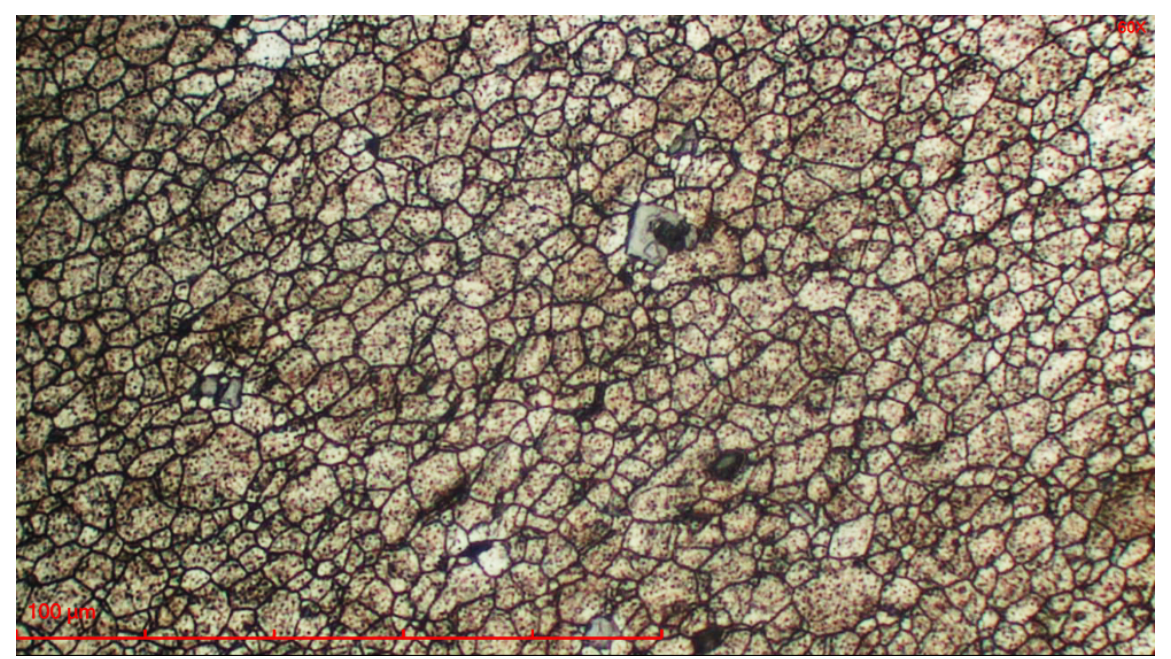

Figure 5. Optical micrographs, (a) AA6082 base material, (b) AA8011 base material, (c) Friction stir processed FSWed AA6082/AA8011 joint advancing side, (d) Friction stir processed FSWed AA8011/AA6082 joint advancing side, (e) Nugget zone (AA6082/AA8011) and (f) Nugget zone (AA8011/AA6082).

\section{Fatigue life cycle}

Figure 6 shows the stress -number of cycles to failure curves for the AA6082/AA8011 and AA8011/AA6082 friction stir processed FSWed joints. The AA8011/AA6082 joint had a fatigue life of $4.489 \times 10^{5}$ while the AA6082/AA8011 had a a life span of $1.765 \times 10^{6}$. The AA6082/AA8011 had a longer fatigue life cycle compared to the AA8011/AA6082 joint and similar behaviour is alos found in the literature [37-39]. The fatigue life behaviour was found to be in agreement with the findings by Park et al. [20], which reports that the fatigue life increases as the microstructural grains decreases.

\section{Hosted file}

image15.emf available at https://authorea.com/users/324395/articles/452595-materialpositioning-influence-towards-fatigue-strength-of-the-friction-stir-processed-aa8011aa6082-joints

Figure 6. ?-? curves of fatigue test results.

Figure 7 shows the fracture surface of the friction stir processed FSWed joint AA6082/AA8011 joints which failed under fatigue loading. The tests were performed using amplitude at $30 \%$ UTS to $80 \%$ UTS on both joints (AA6082/AA8011 and AA8011/AA6082). During each fatigue loading cycle at the highest stress intensity, the crack growth created a band of markings known as striations on the fractured surface and these striations are very useful in determining crack growth direction [40-41]. The striations are evident in Figure 7(a) to (f), moreover, a cluster of teared dimples were noted in figure 7(b) and in 7(c) few dimples were also observed which are characterization of ductile fatigue fracture [42-43]. Figure 7(a), (e) and (f) also shows particle inclusions as denoted by the doted circles. Figure 8(a) to (e) exhibits the fractographs for the friction stir processed FSWed AA8011/AA6082 joints failed under fatigue loading. In Figure 8(a) to (e) the fractographs all show fine and dimpled micrographs while Figure 8(f) shows a micrograph with fine striations. 

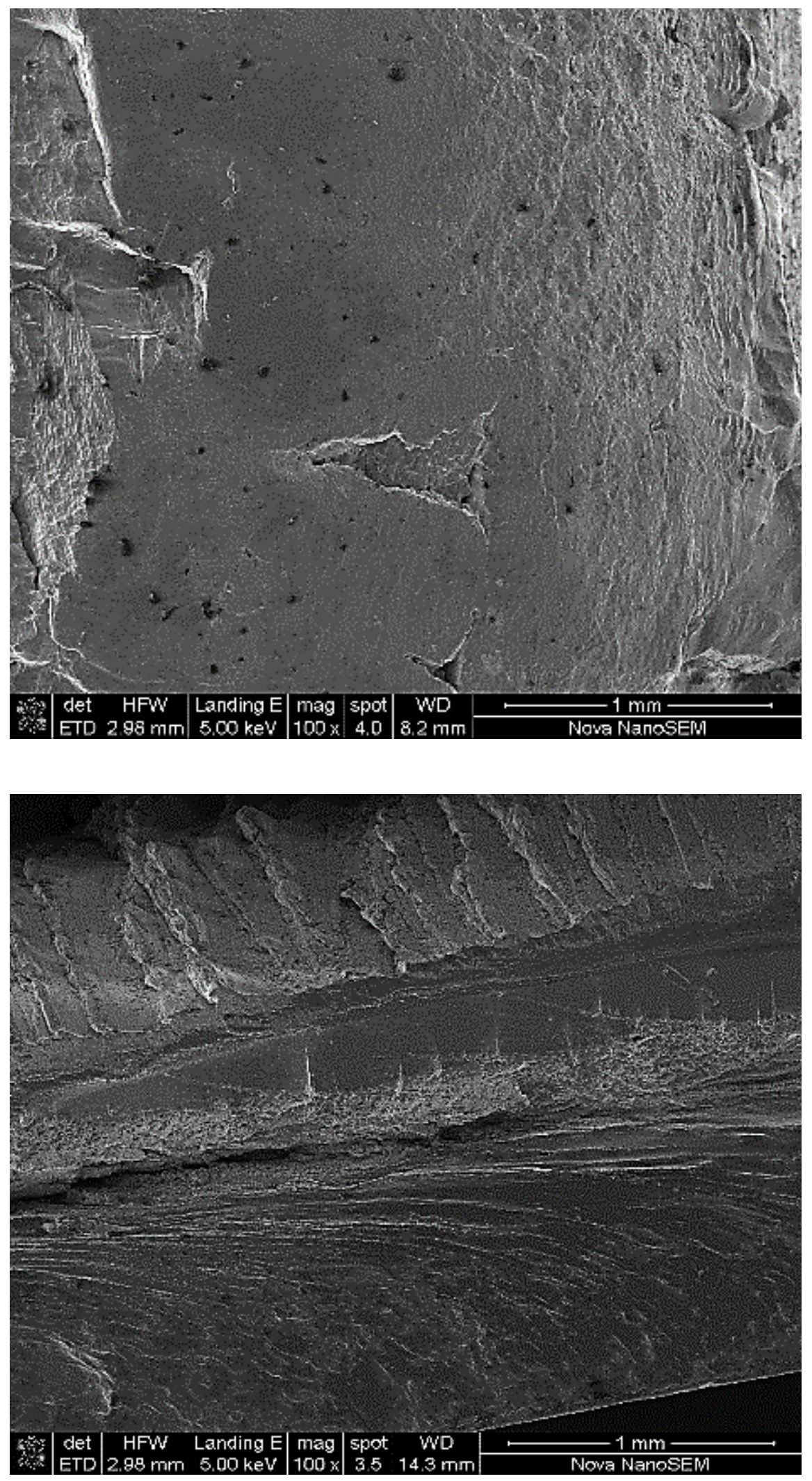

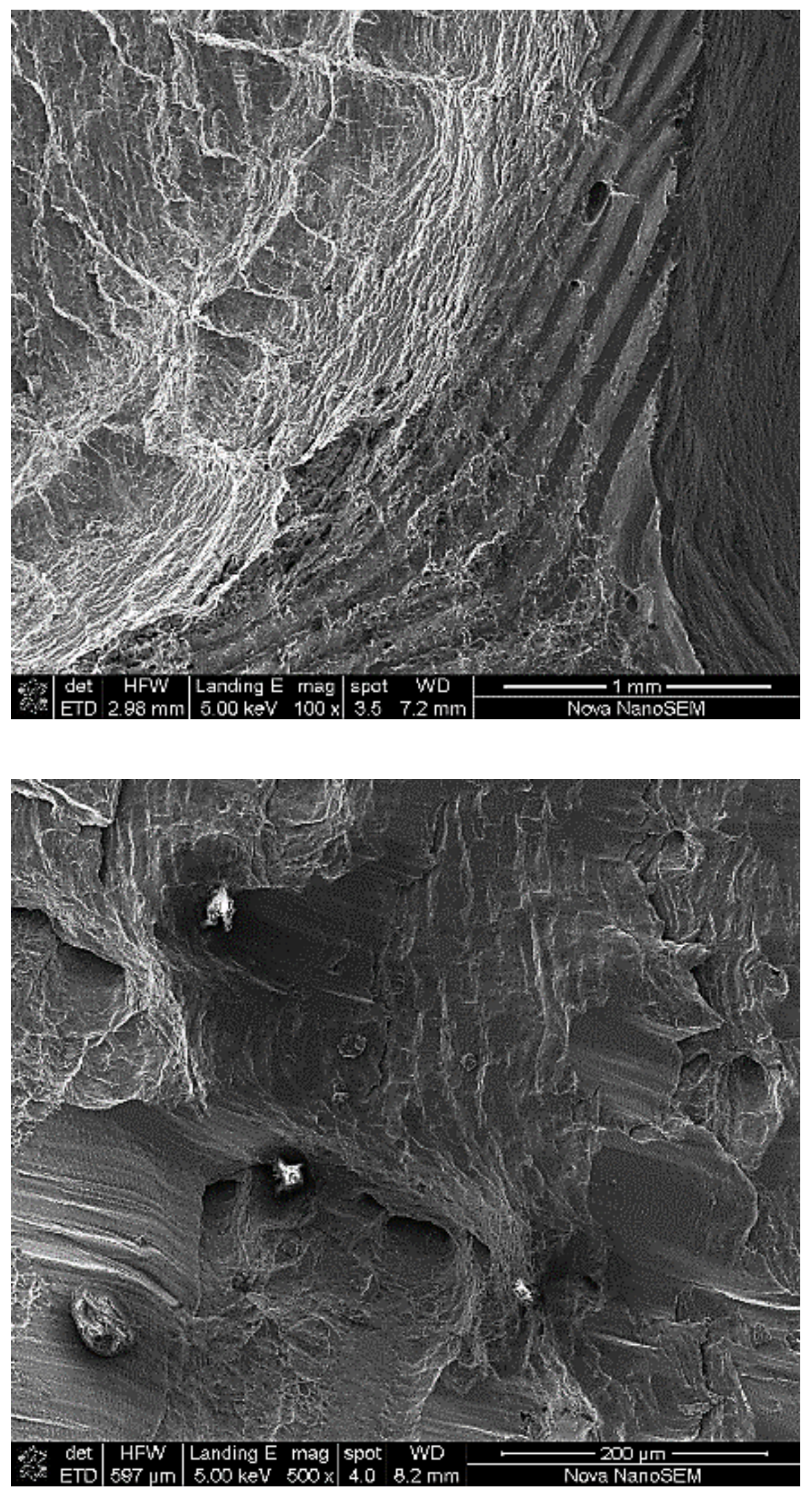

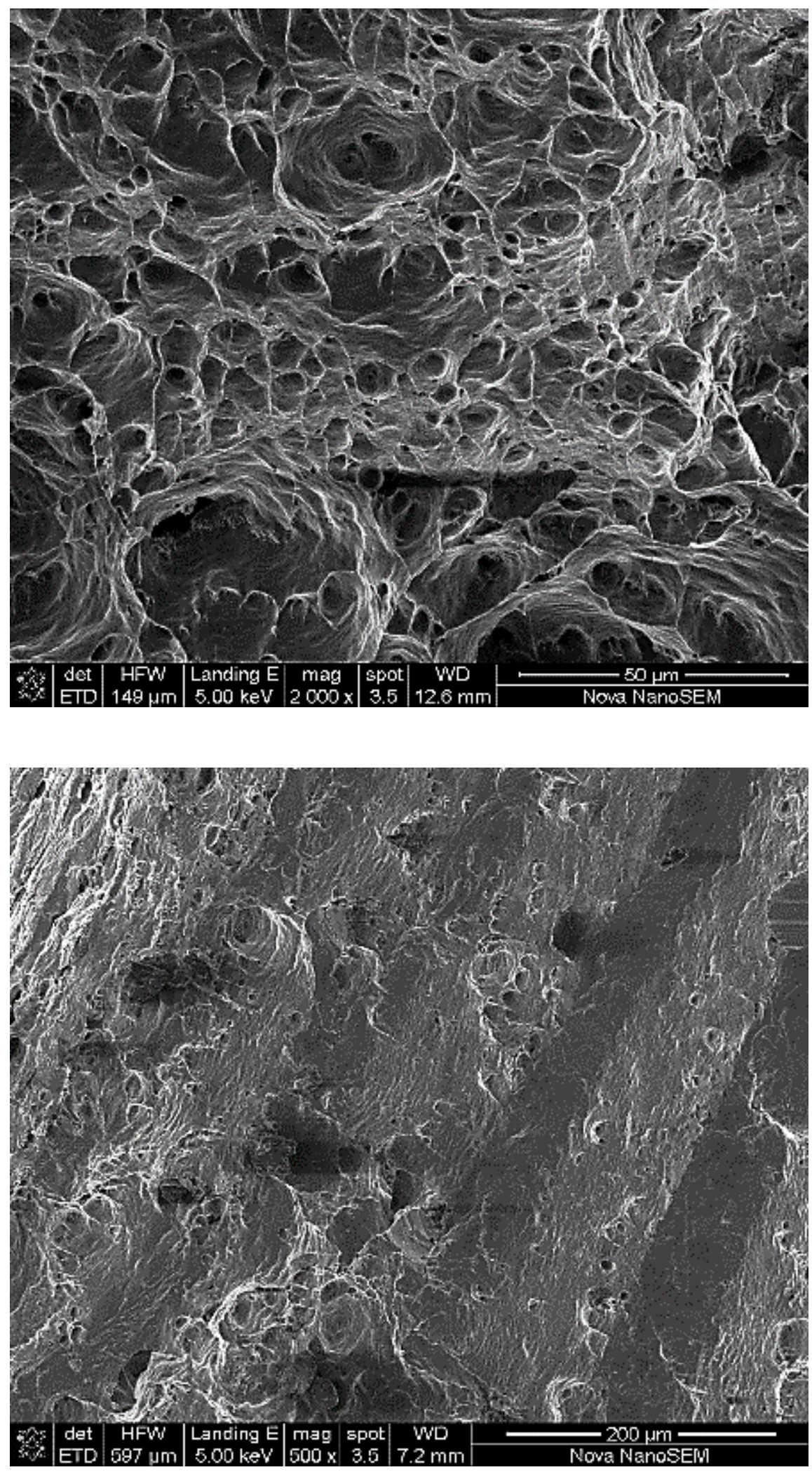

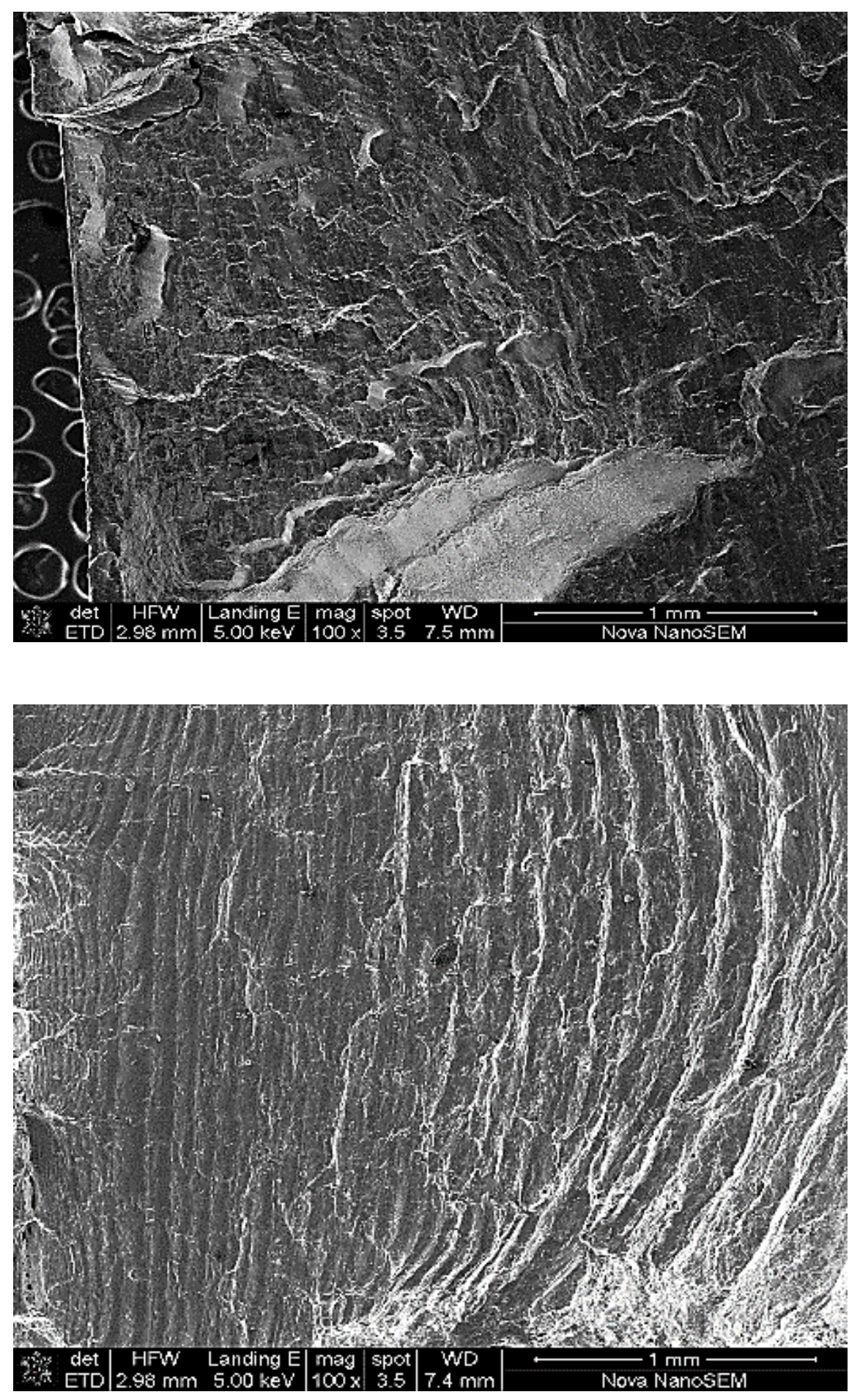

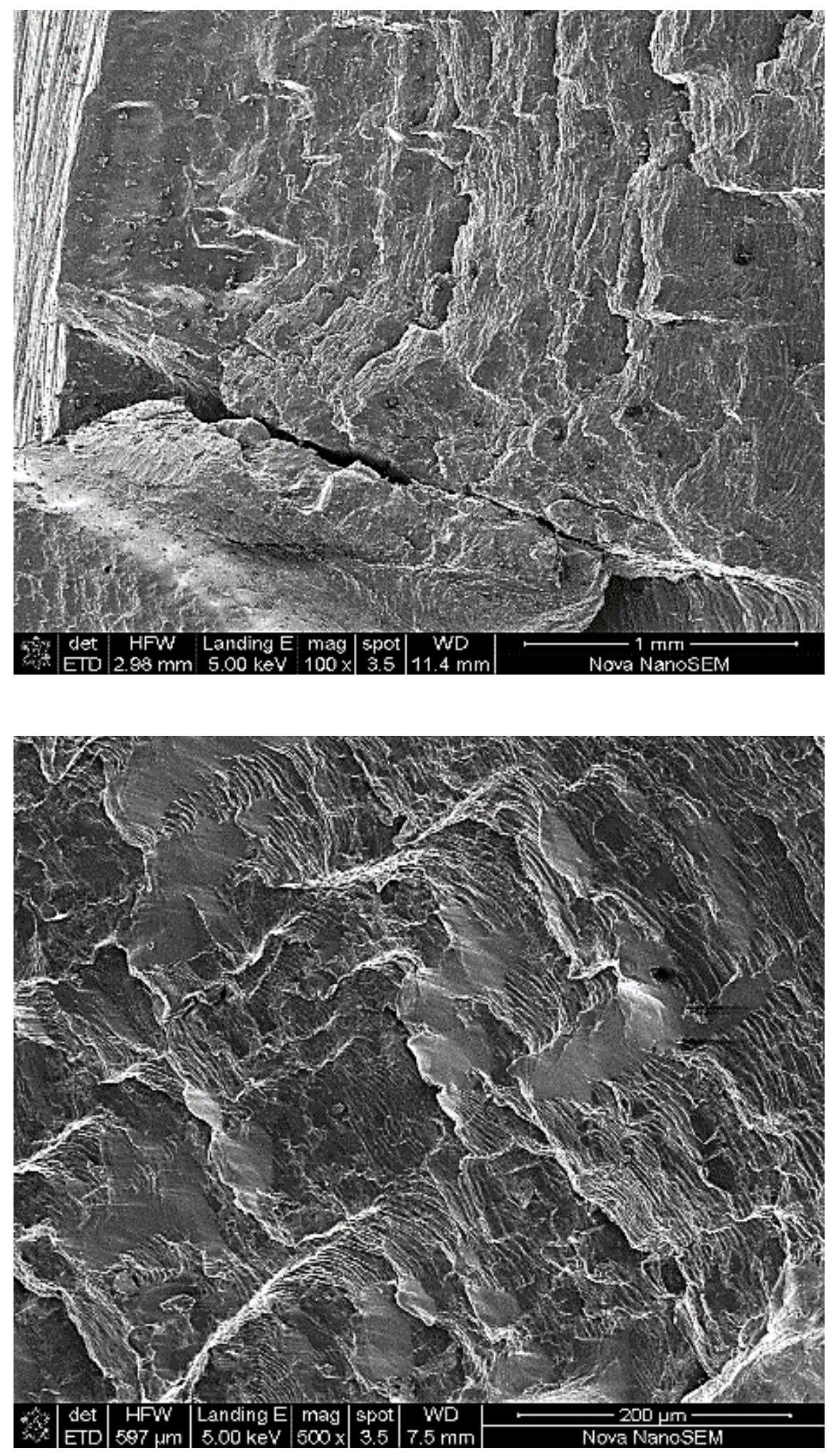

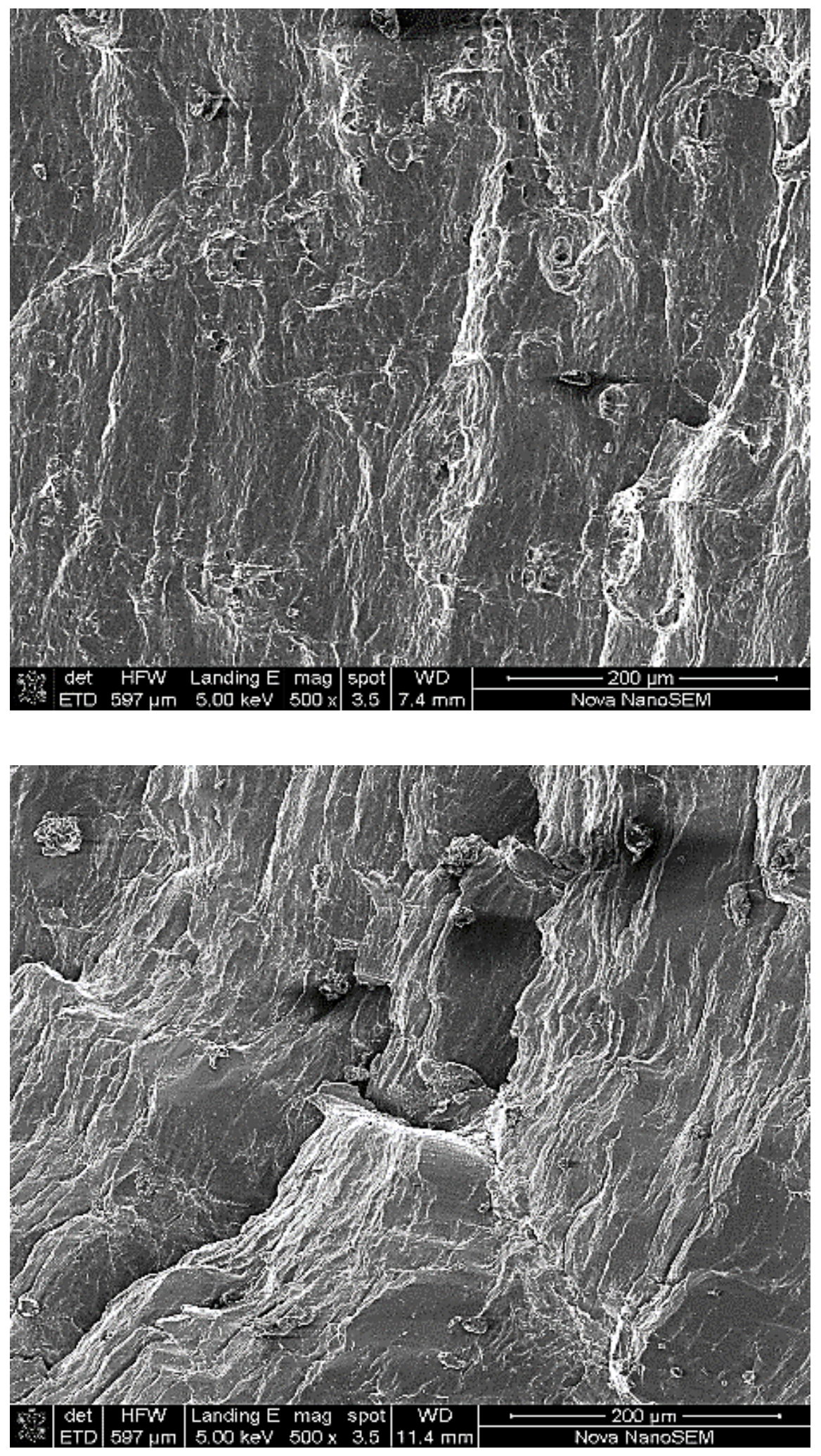

Figure 7. SEM fractographs for friction stir processed FSWed AA6082/AA8011 joints fatigue tests, (a) 30\% 
UTS, (b) 40\% UTS, (c) 50\% UTS, (d) 60\% UTS, (e) $70 \%$ UTS and (f) $80 \%$ UTS.

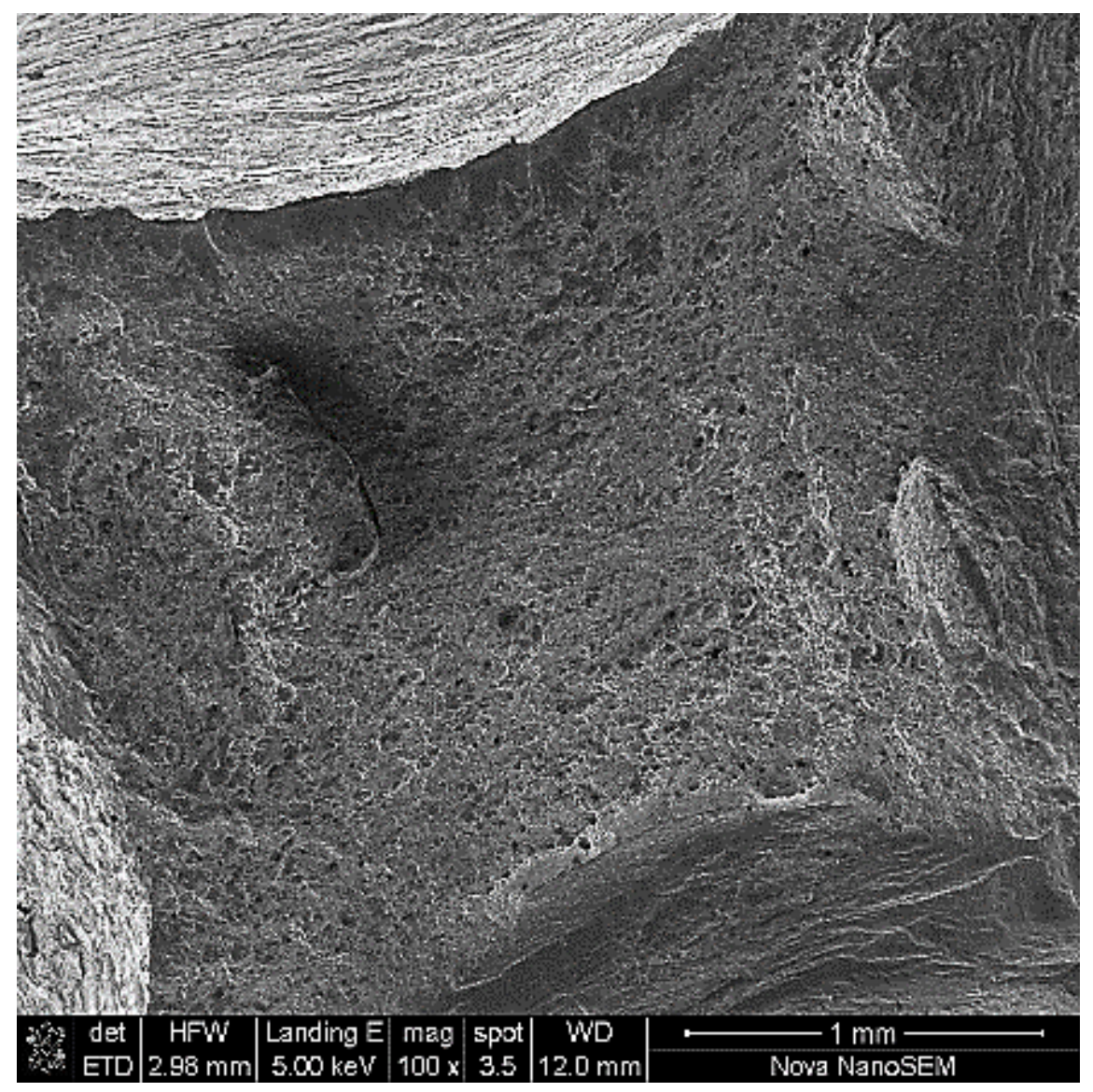




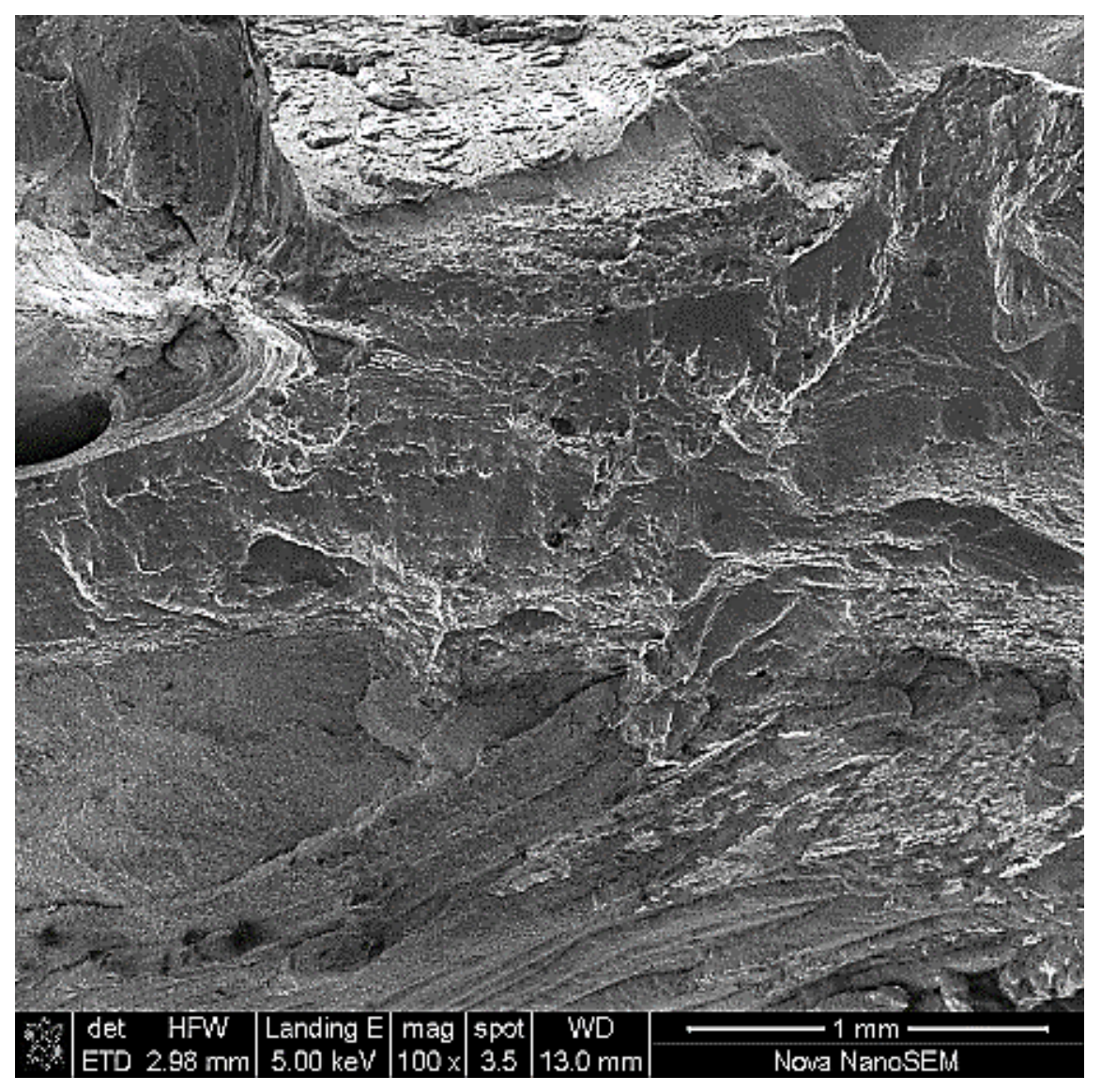




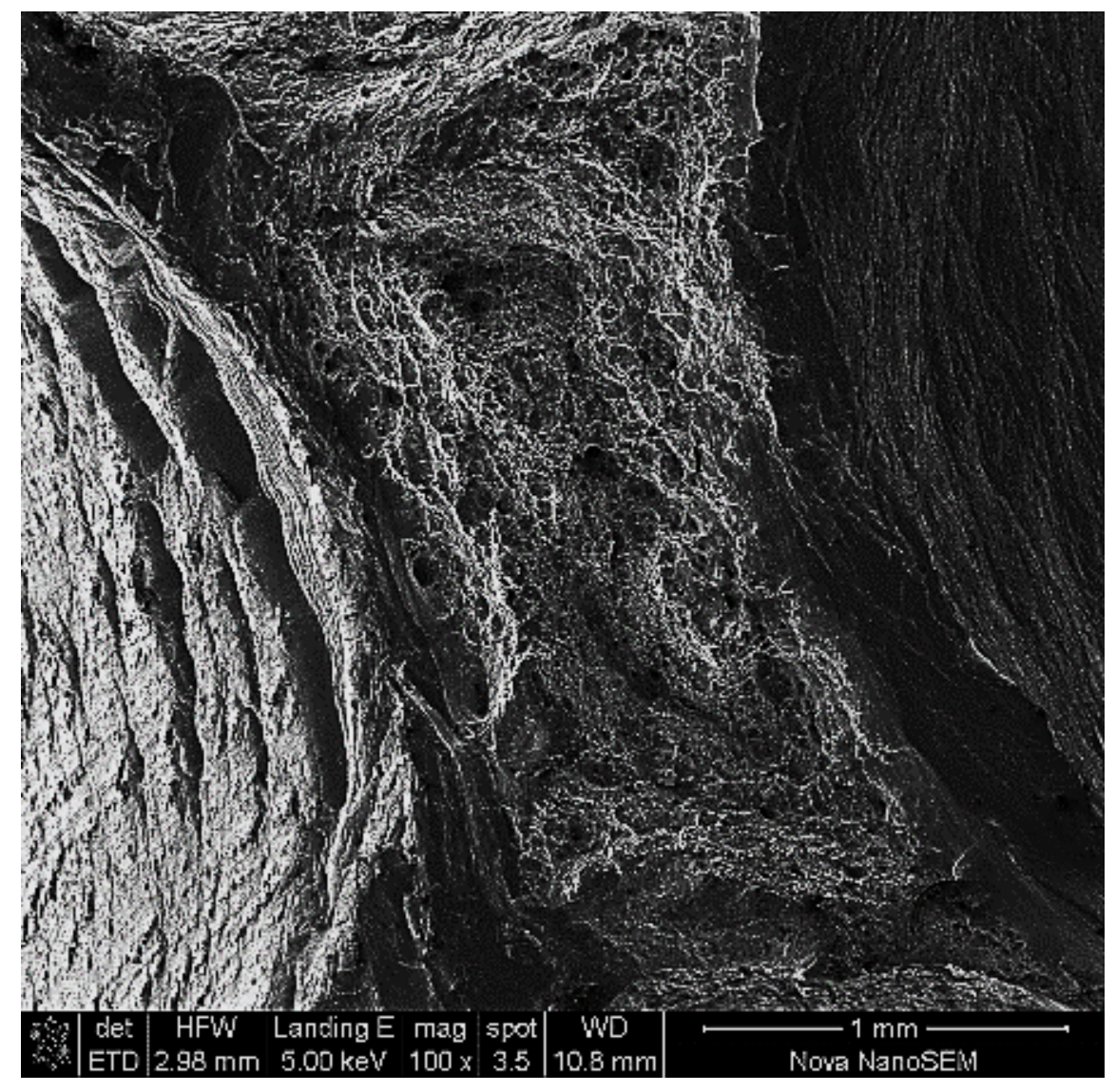




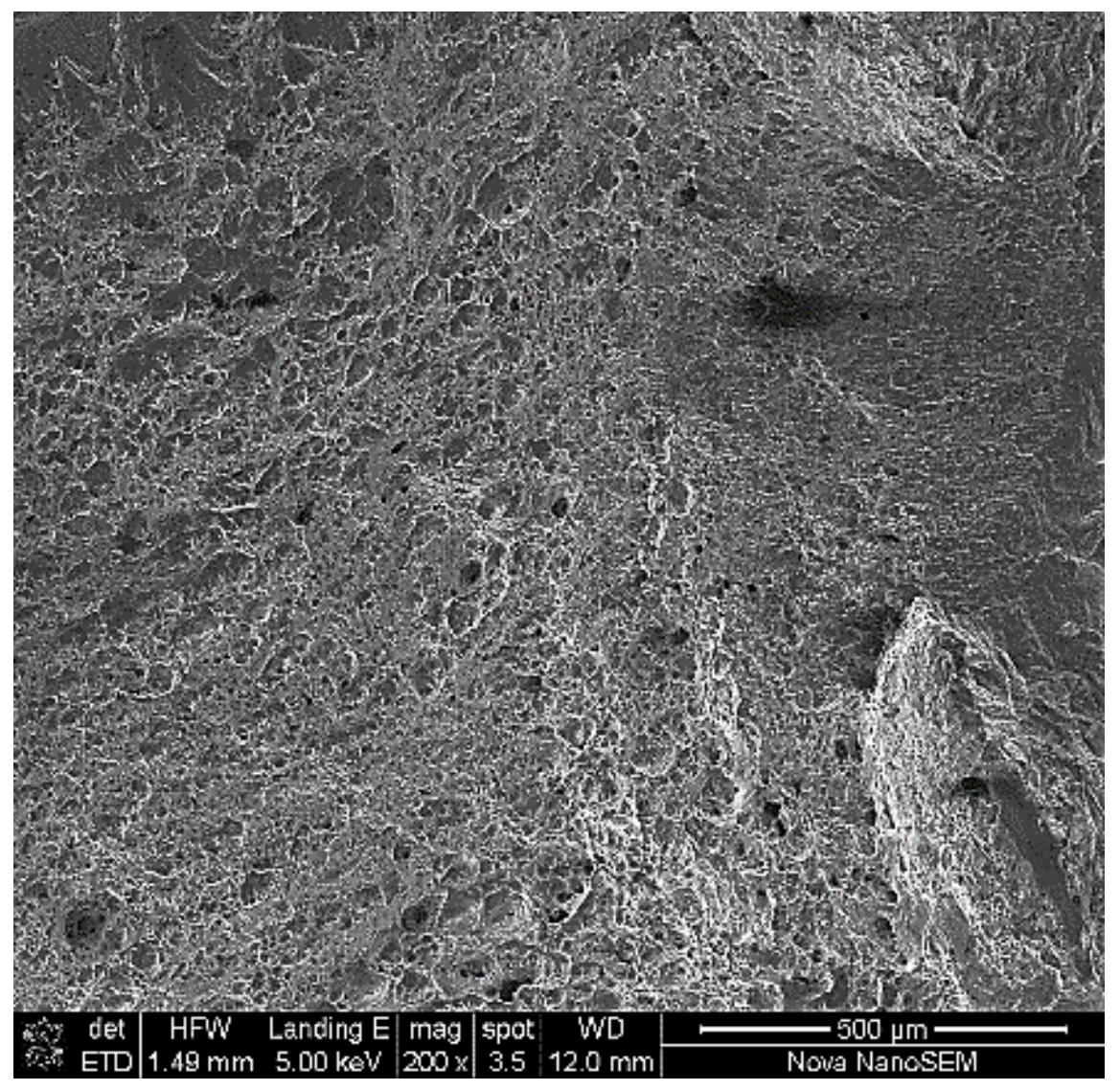




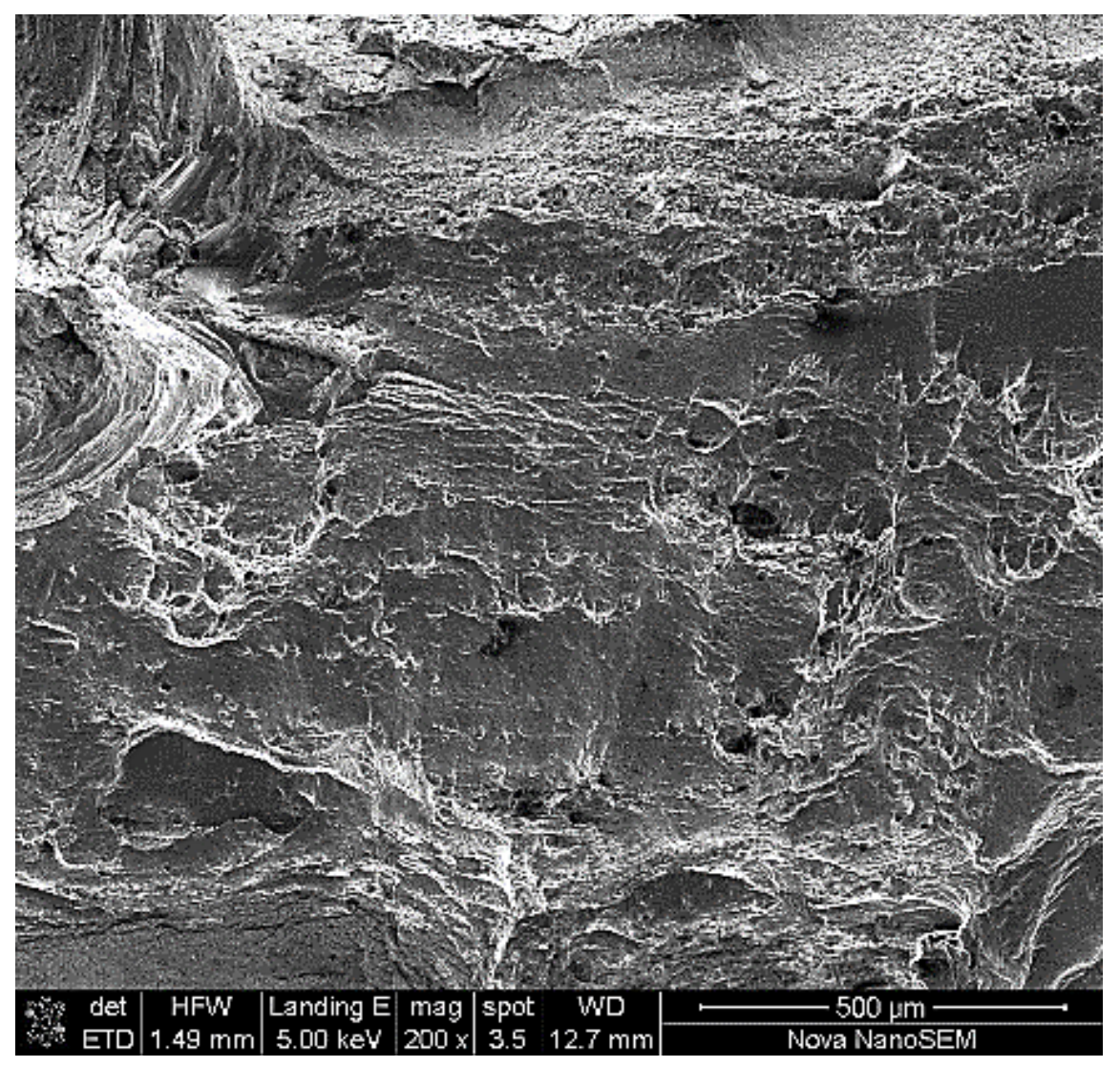




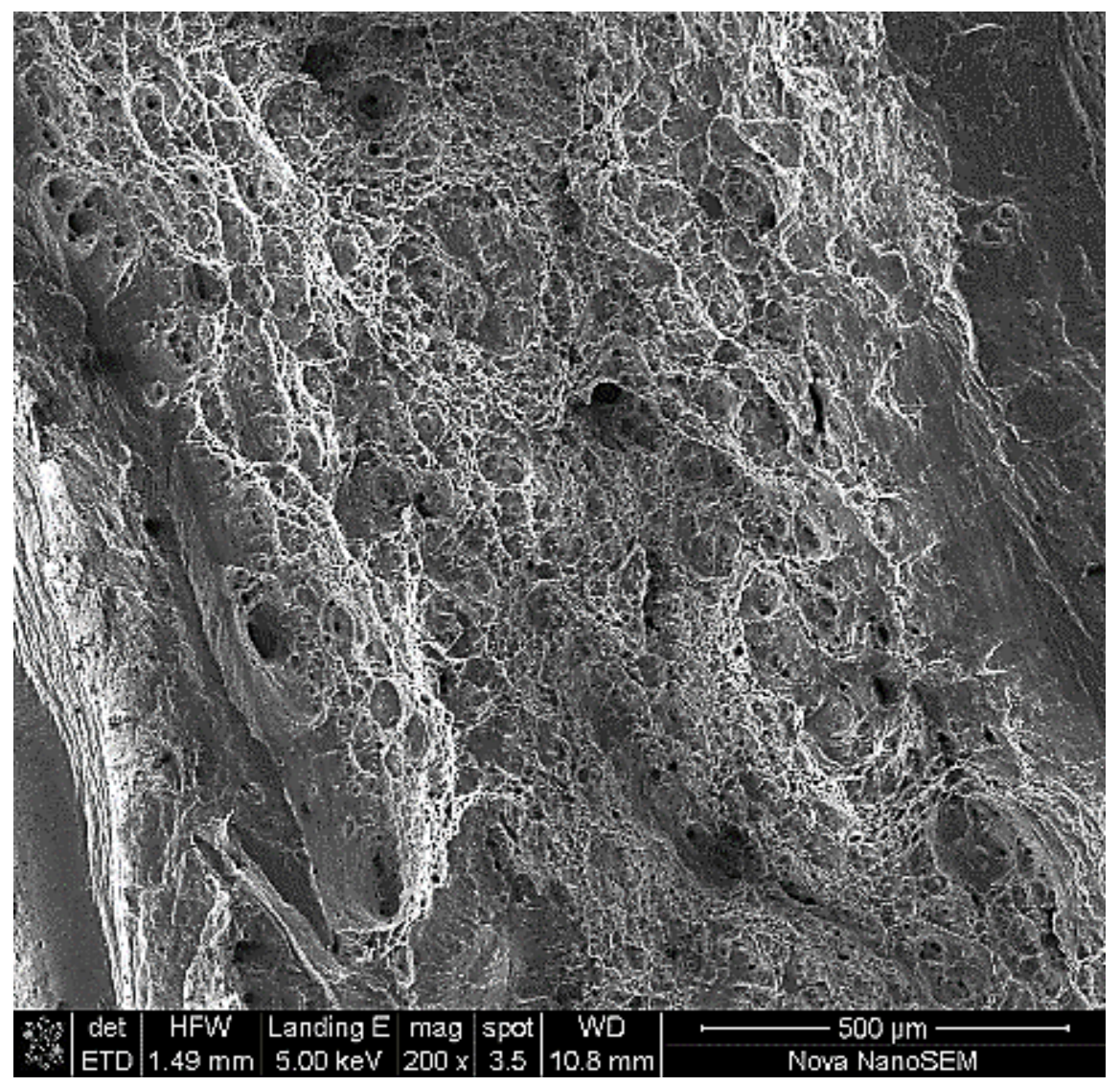




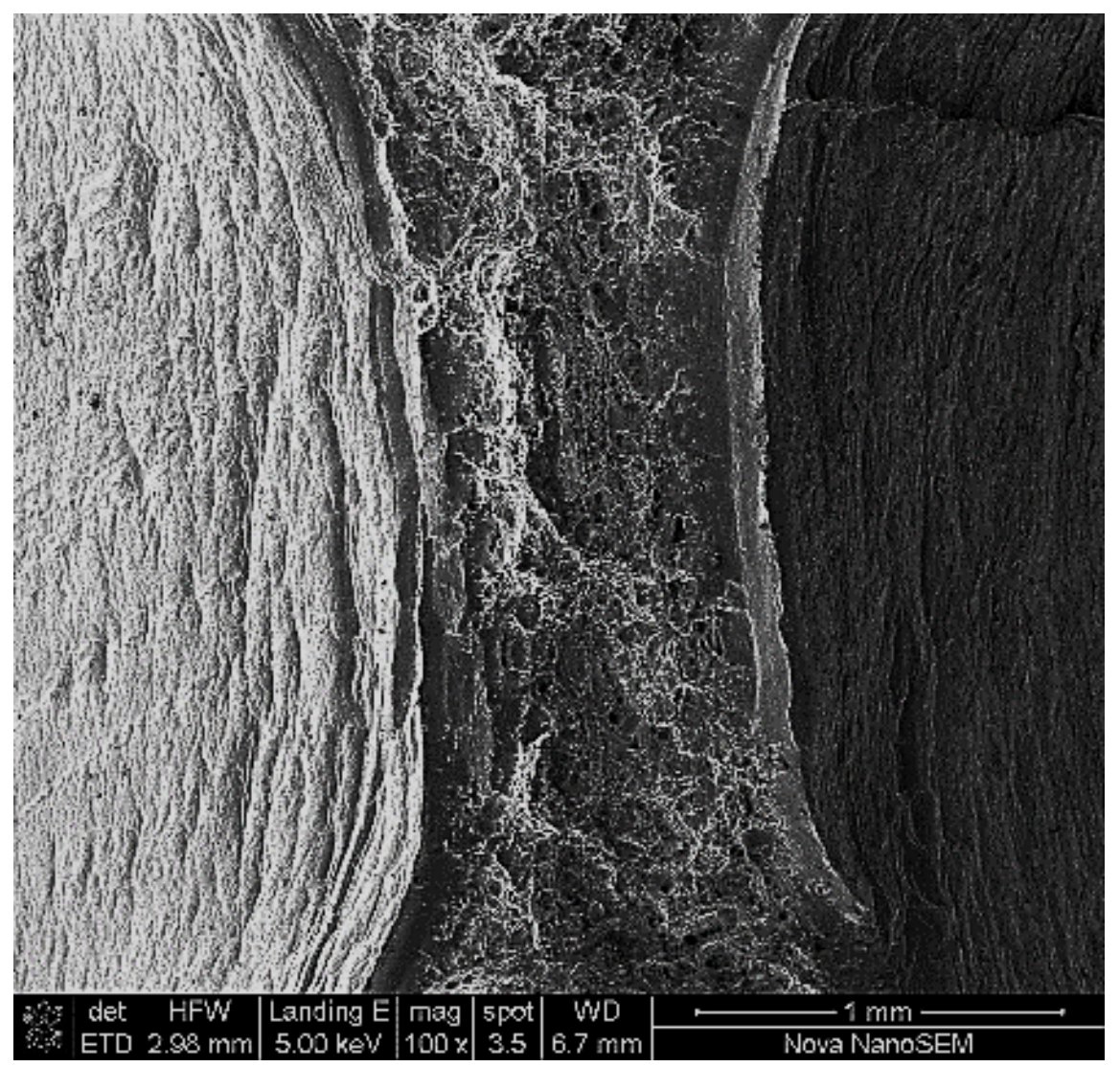




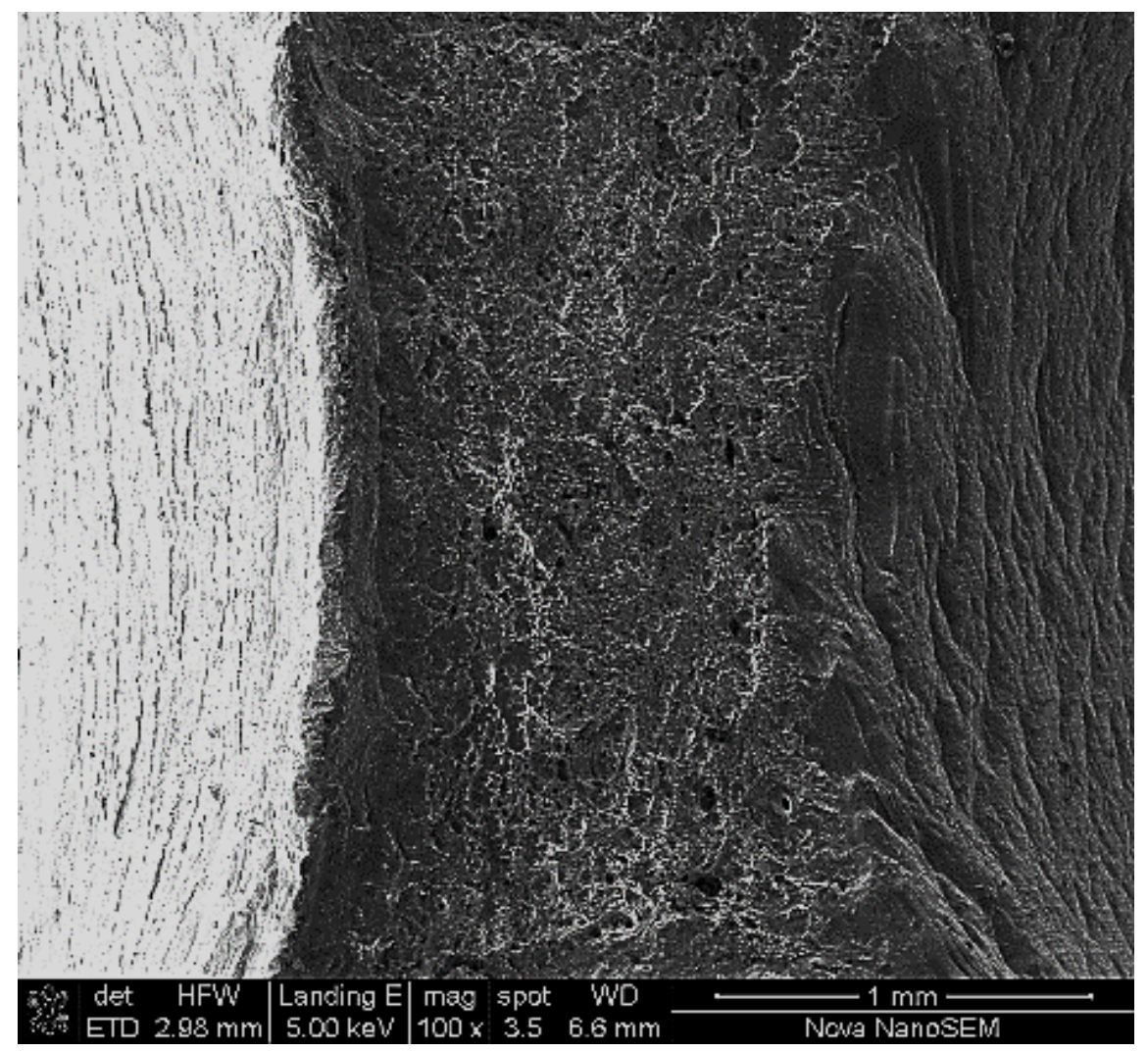




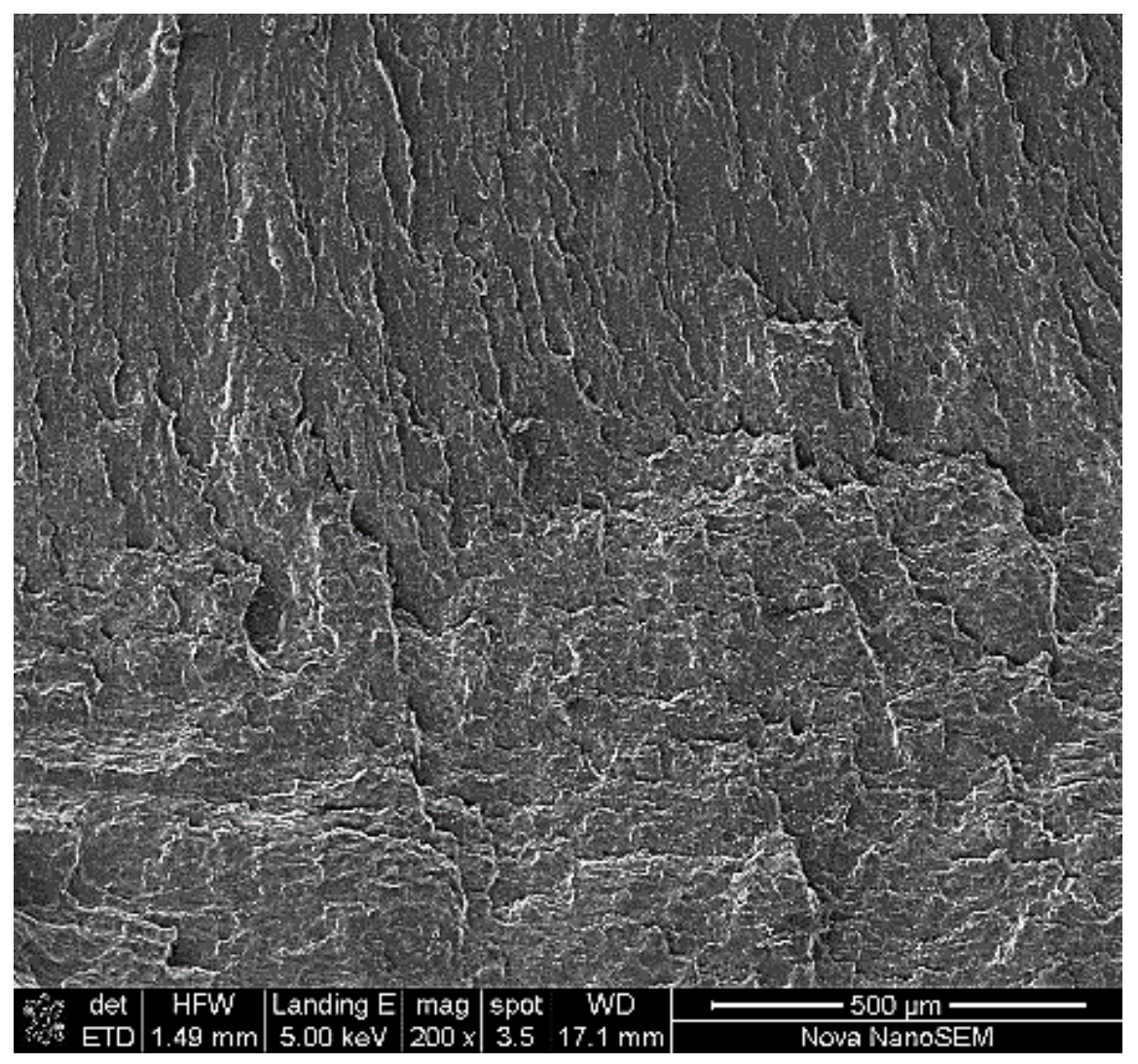




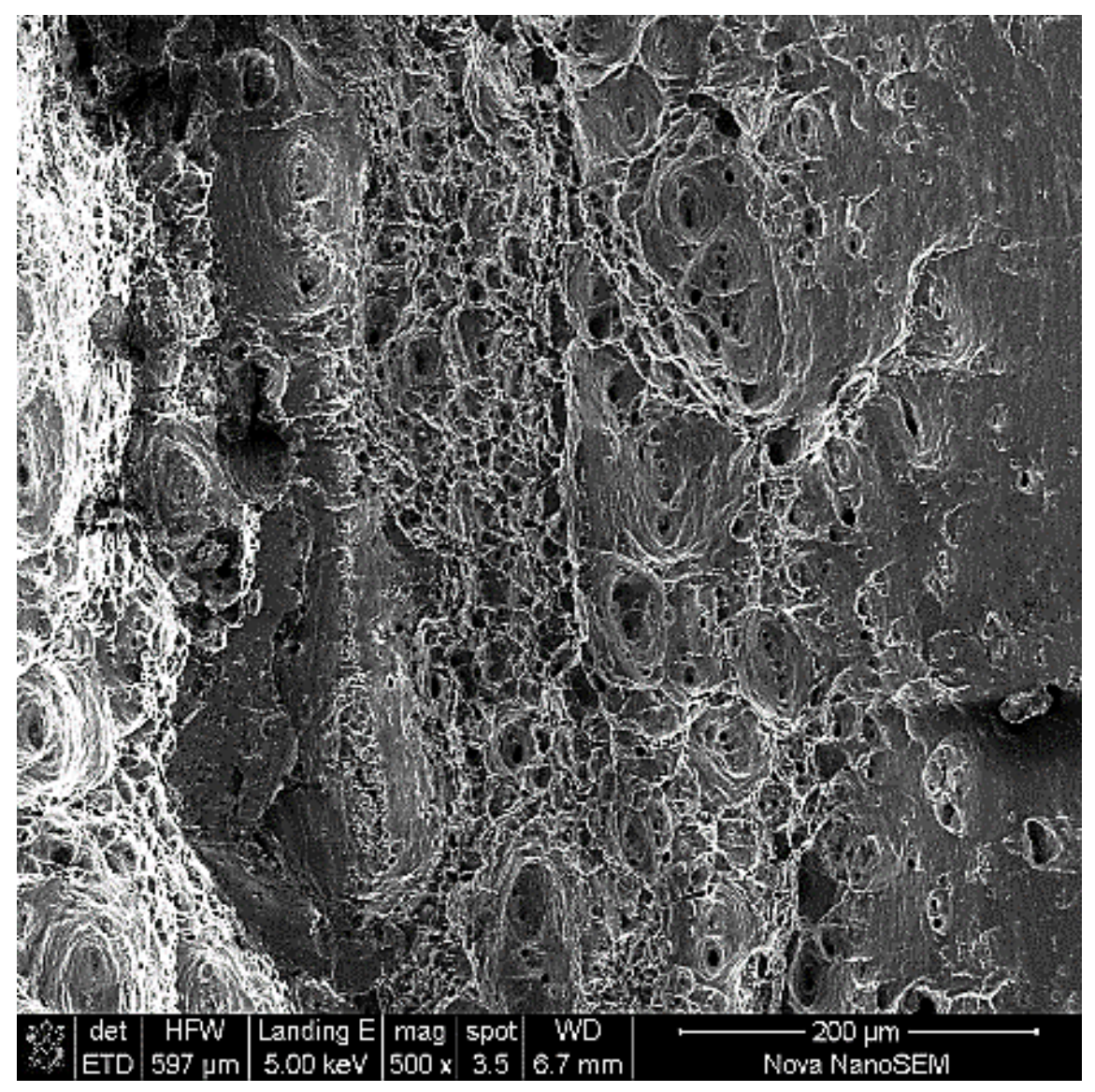




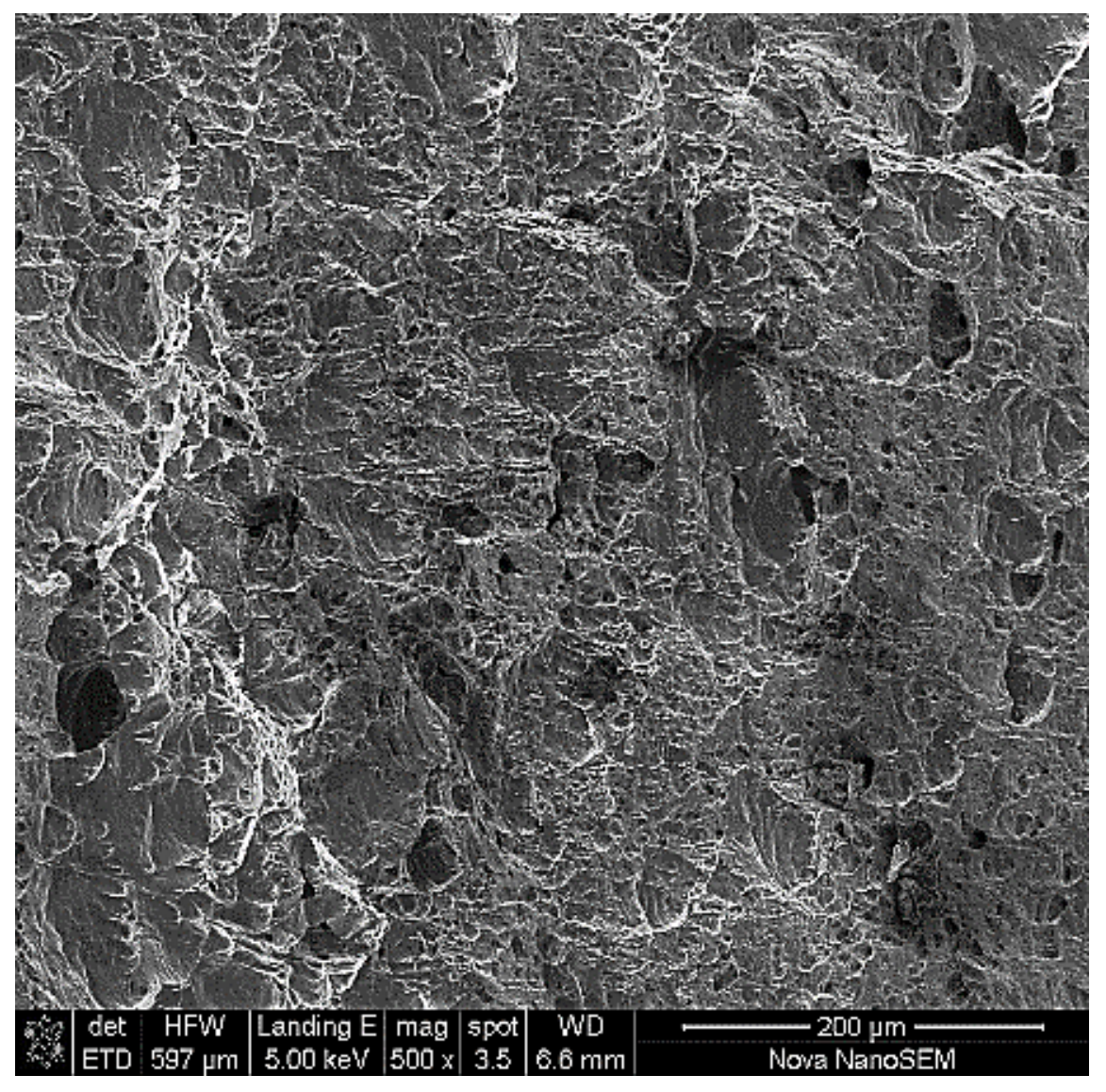




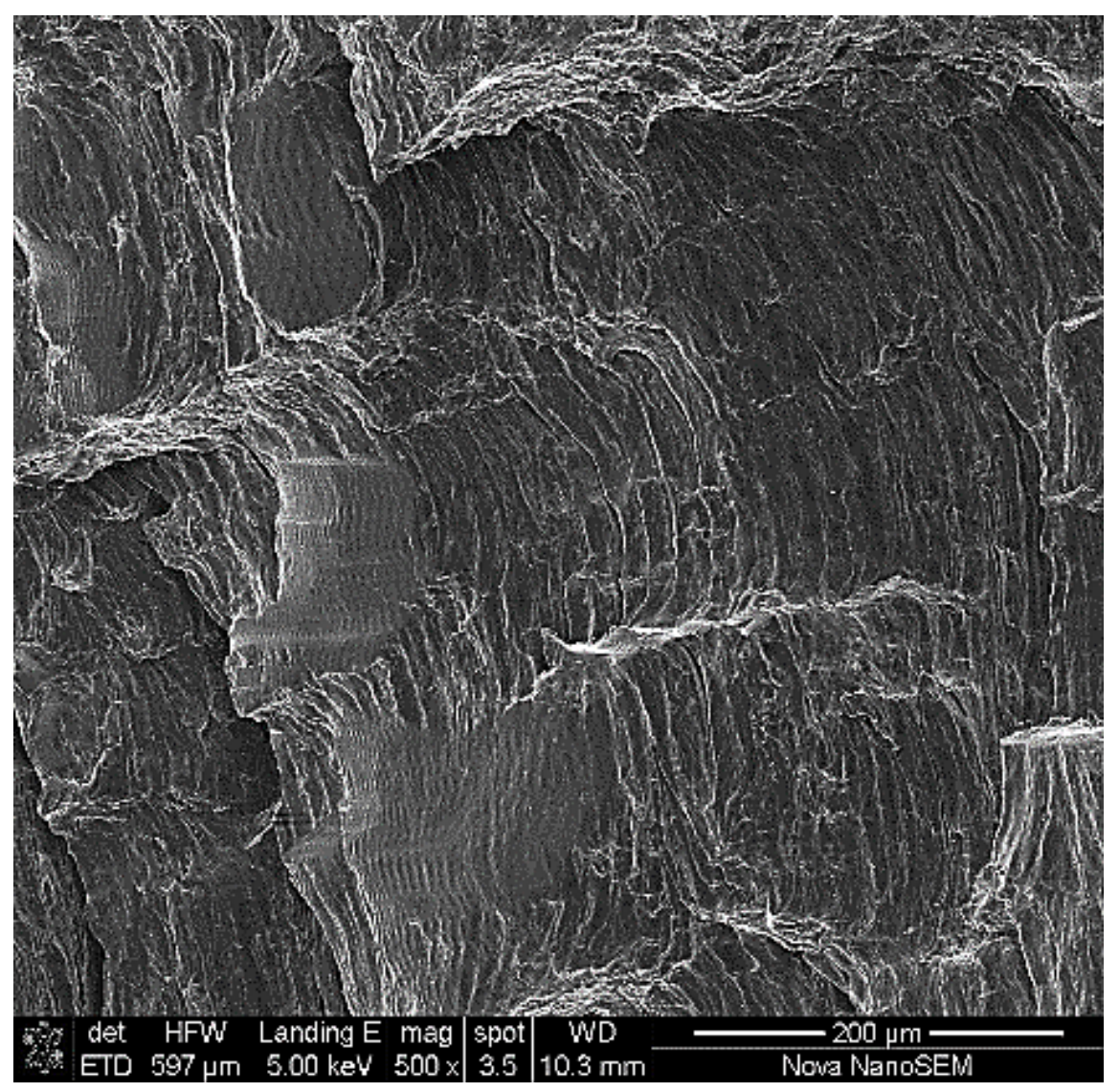

Figure 8. SEM fractographs for friction stir processed FSWed AA8011/AA6082 joints fatigue tests, (a) 30\% UTS, (b) 40\% UTS, (c) 50\% UTS, (d) 60\% UTS, (e) 70\% UTS and (f) $80 \%$ UTS.

\section{Conclusions}

In this study the influence of material positioning on the fatigue strength of the friction stir processed dissimilar FSWed AA6082/AA8011 and AA8011/AA6082 was successfully carried out. Based on the results obtained the following concluding remarks were made:

- The tensile properties of AA6082/AA8011 were found to be higher compared to the joint produced with AA8011/AA6082.

- The microstructural analysis revealed a correlation between material positioning and grain sizes. There was a notable decrease in grain size at the NZ when AA6082 was positioned on the advancing side during processing.

- The stir zone microhardness for the AA8011/AA6082 and AA6082/AA8011 joints was measured to be approximately $60 \mathrm{HV}$ and $80 \mathrm{HV}$, respectively.

- The fatigue strength of AA6082/AA8011 was found to be higher compared to AA8011/AA6082 fatigue strength and this affirmed that the material psotioning contributes towards the fatigue strength of the joint.

\section{Funding}

The authors would like to acknowledge the National Research Foundation (NRF) Thuthuka Grant for funding this study.

\section{Acknowledgements}


The authors would like to thank Miranda Waldron from the SEM department of the University of Cape Town for use of the SEM equipment. Special gratitude also goes to the Cape Peninsula University of Technology for unlimited access to the respective equipment needed for the study.

\section{Data Availability}

Additional data available upon request.

\section{References}

[1] Chen A, Zhang WF, Dong DK, Gong YZ (2020). Fatigue Behavior of Friction Stir Welded Lap Joints for Dissimilar AA7150-AA2524 Aluminum Alloy. IOP Conf. Series: Materials Science and Engineering 751: $1-7$.

[2] Li Y, Murr L E, McClure J C (1999). Solid-state Flow Visualization in the Friction-stir Welding of 2024 Al to 6061 Al.Scripta Materialia, 40(9):1041-1046.

[3] Sarsilmaza F, Caydas U, Hascalik A, Tanriover L (2010). The joint properties of dissimilar aluminum plates joined by friction stir welding. International journal of materials research, 101 (5): 692-699.

[4] Msomi V, Mbana N (2020). Mechanical properties of friction stir welded AA1050-H14 and AA5083-H111 joint: sampling aspect. Metals 10(214):1-17

[5] Chaudhari R, Parekh R, Ingle A (2014). Reliability of Dissimilar Metal Joints using Fusion Welding: A Review. International Conference on Machine Learning, Electrical and Mechanical Engineering (ICMLEME'2014) Jan. 8-9, 2014 Dubai (UAE) : 98-104.

[6] Rambabu G, Naik DB, Rao CHV, Rao KS, Reddy GM (2015). Optimization of friction stir welding parameters for improved corrosion resistance of AA2219 aluminum alloy joints. Defence Technology. 11: $330-337$.

[7] Mofid MA, Abdollah-Zadeh A, Gürza CH (2014). Investigating the formation of intermetallic compounds during friction stir welding of magnesium alloy to aluminum alloy in air and under liquid nitrogen. International Journal of Advanced Manufacturing Technology 71: 1493-1499.

[8] Mishra RS, Ma ZY, Charit I (2003). Friction stir processing: a novel technique for fabrication of surface composite. Materials science and engineering A 34: 307-310.

[9] Senthilkumar R, Prakash M, Arun N, Jeyakumar AA (2019). The effect of the number of passes in friction stir processing of aluminum alloy (AA6082) and its failure analysis. Applied Surface Science 491:420-431.

[10] Abraham R, Mikhail J, Fasihi P (2019). Effect of friction stir process parameters on the mechanical properties of 5005-H34 and 7075-T651 aluminium alloys. Materials Science and Engineering: A 751:363-373.

[11] Mehdi H, R.S. Mishra. Effect of friction stir processing on mechanical properties and heat transfer of TIG welded joint of AA6061 and AA7075. Defence Technology. Inpress.https://doi.org/10.1016/j.dt.2020.04.014

[12] Palani K, Elanchezhian C, Avinash K, Karthik C, Chaitanya K, Sivanur K, Reddy KY (2018). Influence of friction stir processing parameters on tensile properties and microstructure of dissimilar AA 8011-H24 and AA 6061-T6 aluminum alloy joints in nugget zone. IOP Conference Series: Materials Science and Engineering 390: 012108. doi:10.1088/1757-899X/390/1/012108

[13] Silva J, Costa JM, Loureiro A, Ferreira JM (2013). Fatigue behaviour of AA6082-T6 MIG welded butt joints improved by friction stir processing, Materials Design. 51: 315-322.

[14] El-Morsy AW, Ghanem M, Bahaitham H (2018). Effect of Friction StirWelding Parameters on the Microstructure and Mechanical Properties of AA2024-T4 Aluminum Alloy. Engineering, Technology and Applied Science Research 8: 2493-2498. 
[15] Susmel L, Hattingh DG, James MN, Tovo R(2017). Multiaxial fatigue assessment of friction stir welded tubular joints of Al 6082-T6. International Journal of Fatigue 101: 282-296.

[16] Sun Y, Voyiadjis GZ, Hu W, Shen F, Meng Q (2017). Fatigue and fretting fatigue life prediction of double-lap bolted joints using continuum damage mechanics-based approach. International Journal of Damage Mechanics 6: 162-188.

[17] Eslami S, Farahani BV, Tavares PJ, Moreira PMGP (2018). Fatigue behaviour evaluation of dissimilar polymer joints: Friction stir welded, single and double-rivets. International Journal of Fatigue 113: 351-358.

[18] Hussein W , Al-Shammari MA (2018). Fatigue and Fracture Behaviours of FSW and FSP Joints of AA5083-H111 Aluminium Alloy. IOP Conference Series: Materials Science and Engineering 454012055. doi:10.1088/1757-899X/454/1/012055.

[19] Uematsu Y, Tokaji K (2010). Fatigue Behaviour of Friction Stir Processed Cast Aluminium and Magnesium Alloys, Materials Science Forum 638-642: 3727-3732.

[20] Park JU, An G, Kim H, Choi J (2014). Development of Fatigue Life Improvement Technology of Butt Joints Using Friction Stir Processing, Advances in Mechanical Engineering 2014( 943476): 1-14

21. Yamamoto H, Ito K (2018). Effects of Microstructural Modification Using Friction Stir Processing on Fatigue Strength of Butt-Welded Joints for High-Strength Steels. Materials Sciences and Applications 9: 625-636.

[22] Bharti A, Tripathi H (2019). Enhancement of Fatigue Life of TIG-Welded Joint by Friction Stir Processing. In: Chattopadhyay J., Singh R., Prakash O. (eds) Renewable Energy and its Innovative Technologies. Springer, Singapore

[23] Selvaraj G, Karthikeyan T, Mohanadass R, Indhumath S (2015). Investigation on mechanical properties of welded aluminium joints of aa 8011 using friction stir welding. International Journal of Applied Engineering Research 10(13): 11095-11100.

[24] Braga DFO, de Sousa LMC, Infante V, da Silva LFM, Moreira PMG (2016). Aluminium Friction Stir Weld-bonded Joints. The Journal of Adhesion 92(7-9): 665-678.

[25] Mabuwa S, Msomi V (2019). The effect of friction stir processing on the friction stir welded AA1050-H14 and AA6082-T6 joints.Materials Today: Proceedings. Inpress.https://doi.org/10.1016/j.matpr.2019.10.039.

[26] Gandra J, Miranda R, Vilaça P, Velhinho A, Teixeira JP (2011). Functionally graded materials produced by friction stir processing. Journal of Materials Processing Technology 211(11): 1659-1668.

[27] Scialpi A, de Giorgi M, de Filippis LAC, Nobile R, Panella FW (2008). Mechanical analysis of ultra-thin FSW joined sheets with dissimilar and similar materials. Materials and Design 29: 928-36.

[28] Moreira PMGP, Santos T, Tavares SMO, Richter- Trummer V, Vilaca P, DE Castro PMST (2009). Mechanical and metallurgical characterization of friction stir welding joints of AA6061-T6 with AA6082-T6. Materials and Design 30: 180-187.

[29] Ilangovan M, Boopathy SR, Balasubramanian V (2015). Microstructure and tensile properties of friction stir welded dissimilar AA6061-AA5086 aluminium alloy joints. Transactions on Nonferrous Meterial Society China 25:1080-1090.

[30] Cavaliere P, Panella F (2008). Effect of tool position on the fatigue properties of dissimilar 2024-7075 sheets joined by friction stir welding. Journal of Material Processing Technology 206:249-255.

[31] Guo JF, Chen HC, Sun CN, Bi G, Sun Z, Wei J (2014).Microstructural and mechanical properties of dissimilar friction stir welds between AA6082-T6 and AA7075-T651. Material Design 56 185-192. 
[32] Sadeesh P, Kannan V M, Rajkumar V, Avinash P, Arivazhagan N, Ramkumar K, Narayanan S (2014). Studies on Friction Stir Welding of AA 2024 and AA 6061 Dissimilar Metals. Procedia Engineering 75: $145-149$.

[33] Simar A, Jonckheere C, Deplus K, Pardoen T, de Meester B (2010). Comparing similar and dissimilar friction stir welds of 2017-6005 aluminium alloys. Science and Technology of Welding \& Joining 15(3):254-259

[34] Robe H, Zedan Y, Chen J, Feulvarch E, Bocher P (2015). Microstructural and mechanical characterization of a dissimilar friction stir welded butt joint made of AA2024-T3 and AA2198-T3. Material Characterization 110:242-251.

[35] Murr LE (2010). A review of FSW research on dissimilar metal and alloy systems. Journal Materials Engineering and Performance 19: 1071-1089.

[36] Devireddy K, Devuri V, Cheepu MM, Kumar BK (2018). Analysis of the Influence of Friction Stir Processing on Gas Tungsten Arc Welding of 2024 Auminum Alloy Weld Zone. International Journal of Mechanical and Production Engineering Research and Development 8(1):243-252.

[37] Kumar G, Kumar R (2020). Optimization of process parameters of friction stir welded AA5082-AA7075 butt joints using resonance fatigue properties. Bulletin Of The Polish Academy OF Sciences Technical Sciences 68(1): 99-108.

[38] Li H, Gao J, Li Q (2018). Fatigue of friction stirwelded aluminum alloy joints: a review. Applied Science 8(2626):1-19.

[39] Infante V, Braga DFO, Duarte F, Moreira PMG, de Freitas M, de Castro PMST (2015). Study of the fatigue behaviour of dissimilar aluminium joints produced by friction stir welding. International Journal Fatigue 82(2):310-316.

[40] Rodriguez RI, Jordon JB, Allison PG, Rushing T, Garcia L (2016). Low-cycle fatigue of dissimilar friction stir welded aluminum alloys. Materials Science and Engineering: A 654: 236-248.

[41] Song SW, Kim BC, Yoon TJ, Kim NK, Kim IB, Kang CY (2010). Effect of welding parameters on weld formation and mechanical properties in dissimilar Al alloy joints by FSW. Materials Transactions 51 (7): 1319-1325.

[42] Abbasi S, Esmailian M, Ahangarani S (2018). Investigation of the microstructure, micro-texture and mechanical properties of the HSLA steel, hot-rolled and quenched at different cooling rates. Metallography, Microstructure, and Analysis (7):596-607.

[43] Theocaris PS (1986). Yield criteria based on void coalescence mechanisms. International Journal of Solids and Structures 22(4) 445-466. 